\title{
The Role of Family Institutions and Deregulation Policies in Explaining Unemployment Risks in Households of Europe
}

Oxana Krutova, a Post-Doctoral Researcher, University of Tampere, Faculty of Social Sciences, Work Research Center, Kalevantie 5, FI-33014, Tampere, e-mail: oxana.krutova@tuni.fi mob.: +358449895132

Abstract

This research dealt with the old, but unsettled, question of the extent to which different European welfare regimes and household strategies minimize the risk of unemployment. We statistically processed the EU Labour Force Survey microdata for 29 European countries, covering the period from 2006 to 2016. Utilizing representative data and multilevel analysis, this research redresses the lack of understanding of how different household types buffer and mediate the risks of unemployment. The evidence suggests that choosing the strategy of breadwinning, familization of care or decommodification of labour, male-breadwinner households are more liable to increasing risks of unemployment than other types of households. However, male-breadwinner households remain more resilient against the influence of macroeconomic shocks.

Key words: unemployment risks, household, decommodification, employment protection, welfare regime 


\section{Introduction}

Times of austerity generate unique types of unemployment behaviour. The European welfare state has undergone a massive transitional process, accompanied by rising chronic unemployment rates and growing inequality and poverty in countries with different welfare regimes. With the growth of globalization processes, many national states are struggling to coordinate new European integration policies and to reform social protection systems due to market failures and badly functioning and malfunctioning labour markets, which in many respects produce and overload existing social programmes (Esping-Andersen 1996; EspingAndersen and Regini 2000; Scharpf 1999). All this leads to instability in careers, demands for flexible adjustment, changing family arrangements and growing dissatisfaction with the welfare state’s capacity to address emerging new demands (Mishel and Bernstein 1993).

The most widely accepted explanation for high European unemployment is that European-type welfare state institutions create frictions leading to 'Eurosclerosis' (Dolado et al. 1996; Card and Krueger 1995; Buechtemann 1993; Blank 1994; Bentolila and Bertola 1990). Most economists use the concept of labour market rigidities to describe practices and regulations that inhibit automatic market clearing, (e.g., through decommodification) (Giersch 1985; Siebert 1997; Scarpetta 1996).

On the other hand, earlier studies undoubtedly showed that the resources of individuals and households, welfare state institutions and policies have both direct and indirect impacts on how unemployment risks are buffered. Imperfect interplay between these three aspects of welfare can even have a more negative effect on the labour market, if societies are highly overregulated and labour markets are especially rigid (Esping-Andersen 1999, 2002; Breen 2005; Siebert 1997). The contemporary post-industrial job disease is not necessarily the result of rigidities, or 'Eurosclerosis'; a possible explanation concerns the lack of capabilities to manage the post-industrial family. 
For example, the investigation of Irwin and Morris (1993) into social security disincentives in relation to employment, argued that unemployment 'strategies,' regarding household income maintenance, are patterned in relation to labour demand and occupational opportunities of spouses; they also maintain the social security structure strongly disincentivizes working women married to unemployed men. Harkness and Evans (2011), based on EU LFS data, found that the factor of economic recession directly affects the distribution of job losses across households, such that working women whose partners lost their jobs in times of recessions are more likely to remain in work than before, thereby mediating the growth in workless couple households.

Continuing this line of research into unemployment risks, Clasen and Koslowski (2013) argued that spouses in better-earning households perceive their current job and personal employability as providing some security and regard the prospect of occupational redundancy pay as a major source of income protection; they also maintain state benefits, private insurance and savings are of only marginal significance for such couples. Griffiths (2017) found twoparent families with dependent children to be at lower risk of poverty and significantly less reliant on state financial help than lone-parent households. Clearly, therefore, aspects of welfare state support have been strongly influential in partnering decisions and living arrangements.

We will now address these issues by discussing the extent to which different types of strategies that households and welfare regimes use to address the risk of unemployment. Based on representative data and advanced statistical methods, this research seeks to answer the following three research questions:

- What are the household influences on the risk of being unemployed (inside-household effects)?

- What are the household influences on the consequences of being unemployed (strategies in combating unemployment due to familization and decommodification)? 
- How does deregulation affect the dynamics of unemployment risks in households (labour market deregulation, economic deregulation and time-effect)?

In this way, the paper contributes to the sociological theory of labour markets and provides a better understanding of how different household types buffer and mediate the risks of unemployment. The empirical analysis is based on the European LFS, as well as involving the usage of novel multilevel analysis statistical solutions, which determine the impact of macro-level and micro-level factors.

This article is organized as follows: Section 2 provides theoretical reflections regarding the inside-household, macro-economic and deregulation effects on risks of unemployment in households. Section 3 describes the data set, variables and statistical method used. Section 4 provides the descriptive evidence and results of the multilevel analysis. Section 5 discusses and concludes the article. Finally, Sections 6 and 7 are respectively the Bibliography and the Annex.

\section{Theory}

\subsection{Resource Theory: The Household as a Buffering Mechanism of Unemployment Risks}

The evidence shows that labour institutions reduce the dispersion of earnings and income inequality, thus altering incentives and having a major impact on one important outcome: the distribution of income (Freeman 2005; Ehlert 2012, 2015, 2016; Bryan and Longhi 2015). The institutional effect is linked to information hypotheses and qualifications, because dual-earner households often have higher levels of education and double coupling to a working life compared to others (Holmlund and Lang 1985). This is a common presumption regarding any such 'added worker effect' (Gush, Scott and Laurie 2015).

In addition, Moen's 'linked lives' idea represents another view when arguing that 'the achievement or failure of dual-career arrangements depends on social relations’ (Moen 2003, p. 10). Previous studies have suggested that unemployed people with greater social support 
cope better psychologically than those without such assistance (Milner et al. 2016). Kortteinen and Tuomikoski (1998) have pointed out that, for the long-term unemployed, coping and staying active depend strongly on social support networks, which, in turn, is connected to family relationships and other social ties. Family relations are of particular importance to the unemployed, because family pursuits can compensate for the lack of work, offering time structures and meaningful activities. When social support fundamentally fails, it adversely effects the long-term wellbeing of unemployed people.

On the contrary, households without a buffering effect are at bigger risk of unemployment and poverty. For example, Carr-Hill (2015) studied the under-represented population in fragile, disjointed or multiple-occupancy households, (e.g., the homeless, those in institutions, urban slums and areas deemed as insecure) and concluded that these 'missing' population sub-groups bias the analysis of income inequalities when representing the poorest population. Gardiner and Millar (2006) focused only on low-paid workers and highlighted the importance of household living arrangements in protecting low-waged individuals against poverty. Some groups (unemployed people, lone parents, large families, people with disabilities and some ethnic groups) have much higher poverty rates than the average, while some events (losing a job, marital breakdown, having children) also expose people to high risk of poverty.

\subsection{Chain Reaction Theory}

The chain reaction theory developed by Karanassou and Snower (2000) was initially based on the NAIRU approach (Non-Accelerating Inflation Rate of Unemployment) proposed by Layard and Nickell in 1986. The natural rate of unemployment, according to the NAIRU approach, has been estimated based on structural features of the labour and goods market, productivity, longterm unemployment, capital stock or long-term real interest rates. Economic policy in advanced economies has long been dominated by the NAIRU approach proposed by Layard and Nickell (1986) with later reconsideration by Layard, Nickell and Jackman (LNJ) (1991) and Nickell 
(1997, 1998). In contrast to the NAIRU model, the LNJ model is more endogenous to aggregate demand: namely wage-push factors that affects real wages and the exogenous mark-up over labour costs and prices (Stockhammer 2004a, 2004b).

Despite multiple attempts to reveal the causes and consequences of unemployment, the persistence of shocks has been still underestimated in LNJ's approach, whereas the impact on exogenous components is overrated in the hysteresis view proposed by Henry et al., 2000. The basic argument, which has been considered in chain reaction theory, was grounded on the hysteresis hypothesis developed by Blanchard and Summers in 1986 and reassessed by Ball in 1999 and 2009. According to the hysteresis hypothesis, the dynamic nature of the labour market pushes unemployment as a result of macroeconomic shocks: a negative demand shock causes firing and, due to its irrelevance upon the wage bargaining processes, leads to downward pressure on wages and inflation. Another aspect concerns regional shocks and their influences on unemployment dynamics. For example, in contrast to the regional model advanced by Blanchard and Katz (1992), Decressin and Fatás (1995), Kunz (2009) and Martin (1997), who focus exclusively on regional shocks, the labour market system model should potentially discriminate between regional and national shock effects.

The chain reaction theory proceeds from the premise that labour market adjustments are related to interplay of lagged effects and growth variables, i.e., the inflation rate of unemployment, the growth rate of the labour force and the demand for 'frictional growth.' Henry et al. (2000) and Karanassou et al. (2008a, 2008b) argue that the NAIRU approach does not serve as an anchor for unemployment due to 'frictional growth;' this is a phenomenon that arises from the chain reaction, or interaction between lagged adjustment processes generated by shocks in the labour market system and growth factors.

Despite a long-term dependence between aggregate demand and unemployment proposed by NAIRU approach, the effects of demand policies on unemployment have not been 
considered by Layard and Nickell in 1986. These critiques have led to vivid controversies during the last three decades, and the surge in unemployment experienced by advanced economies since 2007 has only intensified these debates. It has been argued that the mechanisms, which according to LNJ ensure that the NAIRU act as an anchor, do not operate, because the anchor properties of the NAIRU depend on the 'real balance effects.' The current economic crisis and the rise in unemployment that it has caused have reignited long-standing debates about which policies are better equipped to tackle unemployment. More specifically, it is necessary to make mention of the mechanisms that can facilitate demand policies (the 'policydrive’ model).

According to Bande and Karanassou (2009), one of the key advantages of chain reaction theory is that it enables the effects of capital stock changes on the unemployment rate to be evaluated empirically, in both the short and the long-run. This is in contrast to the standard approaches, which are emphatic that shifts in the capital trajectory have no long-term effect on the unemployment rate (Layard et al. 1991). Another important factor is that the processes are interconnected with one another and with exogenous variables, the result being that external shocks create spillover effects, amplifying their short-run impact on the unemployment rate and extending their duration, while preventing the unemployment rate from converging on an invariant level in the long-term (Karanassou and Snower 1997 and 1998).

\subsection{The Deregulationist Perspective on Unemployment}

According to Siebert (1997), Pierre and Scarpetta (2004), Freeman (2005), Nickell, Nunziata and Ochel (2005) and Lee (2013), labour market institutions have equivocal effects on other aggregate outcomes, such as unemployment: welfare state measures cause deviations from the perfect market model, while 'policies against the perfect market model' otherwise disrupt smoothly functioning markets and create outcomes which deviate from perfect market equilibrium. 
On the other hand, job security regulations, understood as restrictions on hiring and firing, have different background determinants, depending on whether they are directed at labour market insiders or outsiders. Labour market deregulation, when its remit is limited to the dismissal of workers and imposing of limitations on the firing of new workers, potentially reduces unemployment (Bertola 1990). According to Emmenegger (2009), due to the distributional effects of job security regulations, these regulations benefit a specific group of actors in the labour market: labour market insiders. Therefore, job security may be of minor importance to individuals in a strong labour market position, but it may disadvantage those in the weakest labour market position, such as the long-term unemployed, older people, unskilled workers and women (Sjöberg 2004).

Nevertheless, despite evidence of the positive influence of employment protection legislation (EPL) reforms in reducing youth unemployment, deregulation of fixed-term contracts exacerbates social inequality by contributing to the spread of temporary employment without improving young people’s labour market chances (Gebel and Giesecke 2011, 2016). By testing labour market mechanisms that underlie EPL effects on early career attainment, Gangl (2003) demonstrates that strict employment protection primarily reduces young people's chances of upward mobility. According to Bennett and Möhring (2015), rigorous EPL particularly decreases the probability of early retirement for individuals in regular employment; this is with a consistent with evidence showing the impact of labour market policies on late career employment.

Elmeskov, Martin and Scarpetta (1998) suggest that unemployment benefits are likely to have a greater effect on increasing unemployment in countries with relatively high levels of active labour market policy (ALMP) expenditures. On the contrary, the tightening of eligibility conditions and the reduction of unemployment benefits, as well as the relaxation of fixed-term contract regulations, could have a decidedly positive influence on decreasing unemployment 
rates (Belot and van Ours 2004). On the other hand, the interventional study carried out by Sage (2013, 2015) confirms that ALMPs can improve the health and social environment of unemployment, as decades of research has shown an association with a wide range of deleterious outcomes (loneliness, poor health, reduced wellbeing and increased social exclusion, which is often psychosocial in nature).

According to Bennett (2016), the role of skill-biased technical change (SBTC) affects its interplay with EPL in relation to the unemployment risks of different skill groups: the stronger the skill bias in technical change, the lower the effects on unemployment due to strict EPL. Examining labour market performance from vantage point, it appears that labour market policies are strongly linked to inequality (Estevez-Abe, Iversen and Soskice 2001), as EPL, unemployment benefits and the minimum wage affect the incidence of long-term unemployment and non-standard employment (Kahn 2010; Layard, Nickell and Jackman 1991; Siebert 1997; Bassanini, Nunziata and Venn 2009).

\section{Research Design}

\subsection{Data and Sample}

We statistically processed the EU LFS microdata using RStudio and R 3.0.3. The multilevel modelling was based on two-step, three-level analyses (individual, household, country) with the usage of microdata from the EU LFS for 29 European countries covering the period from 2006 to 2016, resulting in a sample of 3,006,433 people (aged 15-64 years). We surmised that random effects (including unemployment rates) and fixed effects impact the dynamics of the unemployment rate differently, depending on the type of household. We also used EPL statistics, OECD statistics and statistics on macroeconomic indicators for the estimation of macro-institutional and macroeconomic impacts on the unemployment rates within households.

We generated the variable 'type of household,' based on the conditions of marital status and ILO status. Table 1 in the Annex presents a distribution of the sample, based on 
household type and countries of Europe. Type 1, 'couple, both employed' (dual-earner model), includes households in which both spouses are employed. Type 2, 'single, employed' (singleearner model), includes households in which a single adult is employed. Type 3, 'single, not employed' (single-unemployment model), includes households in which a single adult is unemployed, inactive or in military service. Type 4, 'couple, male employed' (malebreadwinner model), includes households in which one spouse (the man) is employed and the other spouse (the woman) is unemployed, inactive or in compulsory military service. Type 5 , ‘couple, female employed’ (female-breadwinner model), includes households in which one spouse (the woman) is employed and the other spouse (the man) is unemployed, inactive or in compulsory military service. Type 6, ‘couple, neither partner is employed' (dualunemployment model), includes households in which both spouses are unemployed, inactive or in compulsory military service.

\subsection{Micro-Level Variables}

Our basic variable at the individual level is ‘unemployment rate' (URATE). The unemployment rate is calculated by expressing the number of unemployed persons as a percentage of the total number of persons in the labour force (the sum of the number of persons employed and the number of persons unemployed). Following conventions for the estimation of the unemployment rate devised by the International Labour Organization, we calculated a general index based on the equation:

$$
\operatorname{URATE}_{(a, g, e, y)}=\left(\frac{\text { Unemployed }_{(a, g, e, y)}}{\operatorname{Unemployed}_{(a, g, e, y)}+\text { Employed }_{(a, g, e, y)}}\right) * 100
$$

where $\boldsymbol{a}$ means one of the age groups, $\boldsymbol{g}$ means gender (male or female), $\boldsymbol{e}$ means one of three educational levels (higher, medium or lower) and $y$ means the years of observation (2006-2016).

The following variables were also considered (Table 2 and Table 3 in the Annex present descriptive statistics on variables). The 'sex' variable includes two genders: male and female. This dummy variable is considered in the model as a variable factor, which includes 
two dimensions: ' 1 ' for men and ' 2 ' for women. The 'age' variable is normally in five-year age bands (0-4, 5-9 etc.). This variable is aggregated in the anonymized LFS microdata in these five-year age bands. That said, we only considered the working-age population: namely, 15-64 year-olds. The ‘education’ variable includes three categories: ‘low: lower secondary,' ‘medium: upper secondary,' and 'high: tertiary level.' We also controlled multilevel models for the presence of children in the household, number of children (aged less than 15 years or less than 25 years), number of persons aged 65 or older, number of employed persons versus employed adults (aged 15 years and more), number of unemployed adults (aged 15 years and more) and number of inactive adults (aged 15 years and more).

We also controlled multilevel models for familialization and decommodification effects. Familialization effect relates to situations where responsibility to provide care and financial support is assigned only to the family, e.g., if a person is looking after children (familialization of childcare) or incapacitated adults (familialization of ill, disabled and elderly care) and is not searching for a job or is working part-time because suitable care services are not available or affordable.

We categorized decommodification effect as referring to a situation where a person can uphold a socially acceptable standard of living, independently of market participation, (e.g., registration at a public employment office and (or) receiving benefits or assistance). We distinguished full decommodification, (e.g., registration at a public employment office and receiving benefits or assistance), partial decommodification, (e.g., registration at a public employment office without receiving benefits or assistance) and limited decommodification (receiving benefits without registration).

\subsection{Macro-Level Variables}

To separate the effects of labour market deregulation on the unemployment rate, we additionally controlled for time-varying structural conditions. In particular, we controlled for the EPL index 
(OECD EPL index), GDP rate and ALMPs (Table 3 in the Annex presents descriptive statistics on variables). While many previous studies have focused on time-constant country differences in the overall EPL index, we relied on time-varying, yearly measurements to account for the exact timing and magnitude of EPL reforms. Following theoretical arguments, we differentiated between regulations governing individual and collective dismissals and regulations governing regular and temporary contracts.

The OECD indicators of employment protection are synthetic indicators of the strictness of regulation on dismissals and the use of temporary contracts. ${ }^{1}$ The OECD EPL indicators measure the procedures and costs involved in dismissing individuals or groups of workers and the procedures involved in hiring workers on fixed-term or temporary work agency contracts. The indicators have been compiled using the Secretariat's own reading of statutory laws, collective bargaining agreements and case law, as well as contributions from officials from OECD member countries and advice from national experts. Employment protection refers to only one dimension of the complex set of factors that influence labour market flexibility. Data range from 0 to 6, with higher scores representing stricter regulation. The indicator for GDP growth rate is the next macro-level variable. We used the GDP growth rate estimated in percentage to a previous year. ${ }^{2}$ Our final variable used in the macro-level analysis was the ALMP index. ${ }^{3}$ We used the amount of public expenditure as a percentage of GDP for the active measures. This indicator reflects expenditure for public employment services, training and employment incentives.

\footnotetext{
1 OECD indicators of employment protection are available at: http://www.oecd.org/employment/emp/oecdindicatorsofemploymentprotection.htm.

${ }^{2}$ Real GDP forecast, Total, Annual growth rate (\%), 2006 - 2016: https://data.oecd.org/gdp/real-gdp-forecast.htm. 3 Online data are available from the statistics for Finland: http://stats.oecd.org/Index.aspx?DatasetCode=LMPEXP.
} 


\subsection{Statistical Methods}

We applied multilevel models with three levels (individuals, household and country), implemented in a two-step estimation procedure, in order to investigate macro-contextual influences on unemployment rates in different household models. We decided on a two-step procedure instead of a simultaneous estimation because this allows a more flexible specification, since all individual-level effects are allowed to vary across types of household and time without imposing any further distributional assumptions (Finch, Bolin and Kelley, 2014).

In the first stage, we estimated the micro-level determinants of unemployment rates in six types of household. We used a random intercept and fixed slope model. In the second stage, we estimated macro-level determinants of unemployment rate by means macro indicators (EPL, GDP and ALMP indices). We also used the random intercept and fixed slope model.

The time variable was included as an indicator to allow for the control of the time factor in the model in the second stage. We used this structure to estimate multilevel models with time-varying effects, which has the advantage of conditioning time-constant characteristics (micro indicators). In this way, we could control for differences in labour market behaviour between types of household in terms of both time-constant and time-varying characteristics (macro indicators). Moreover, we accounted for fixed time effects in this multilevel model to capture unobserved period-specific effects.

\section{Results}

\subsection{Descriptive Results}

In the first stage, we carried out an ANOVA test with Bonferroni correction, which has shown that there are considerable differences in the risk of unemployment between countries $(\mathrm{F}=$ 20197.54, $\mathrm{p}=0.0000)$. Bartlett's test for equal variance has confirmed the high significance of differences between countries on unemployment rate $(\operatorname{chi} 2(28)=1.2 \mathrm{e}+06$, Prob $>$ chi2 $=0.000)$. 
Figure 1 shows the means unemployment rate of the study population, aged 15-64, estimated after the ANOVA test with Bonferroni correction.

$<$ Figure 1 here $>$

Figure 1 shows that countries differ in terms of the unemployment rate, which ranges widely from $2.9 \%$ in Norway up to $15.4 \%$ in Greece. The average across 29 European countries is $6.9 \%$. Among the Nordic countries, often considered to be uniform in their provision of socially-democratic welfare state regimes, Norway (2.9\%), Iceland (4.3\%) and Denmark (5.7\%) and have relatively low unemployment rates, while Finland (7.4\%) and Sweden (8.8\%) have higher unemployment rates than the average for 29 European countries. Among the countries with the highest unemployment rate are several Southern European countries, such as Greece (15.4\%), Spain (15.2\%) and Portugal (11.9\%). The former communist EU new member states can be found among the countries with the highest rates, (e.g., Croatia, 11.7\%, Latvia, 10.8\% and Lithuania, 10.7\%), as well as those with the lowest rates, (e.g., Czechia, 6.1\% and Slovenia, 6.8\%).

\subsection{Multilevel Models}

Table 1 shows the results of linear regression analysis (mixed-effects model fit by REML) with fixed slopes and random intercepts. Reported are unstandardized beta coefficients with standard errors for each covariate. The intra-class correlation (ICC) indicates how much of the total variance is explained by between-person variance: the outcome variable (unemployment rate) can be explained by the properties of the person who provided the rating. ICC rates are rather high (around 83-87\%), which means that individual characteristics play a strong role in explaining the risk of unemployment. The reduction in the log likelihood in the full model, compared to the null model, indicates a statistically significant improvement in the model's fit. 
In the first step, we carried out an ANOVA test with Bonferroni correction, which has shown that there are considerable differences between types in the risk of unemployment $(\mathrm{F}=$ 39014.46, $\mathrm{p}=0.0000)$. Bartlett's test for equal variance has confirmed the high significance of differences between types on unemployment rate (chi2(5) $=6.1 \mathrm{e}+05$, Prob $>$ chi2 $=0.000$ ).

The results corroborate our expectation that inside-household effects differently impact unemployment in households of various types. When considering inside-household effects on risks of unemployment, the research finds that the age and number of children present in a household would likely influence the labour market participation barriers and constraints experienced by households, but also identifies the extent to which in-work or out-of-work welfare transfers play a role in household finances. This could be particularly important for lone-parent-unemployed households, which fit into the household types constructed. However, familialization of care was found to be an important indicator for growing risks of unemployment, especially for male-breadwinner households.

More detailed analysis has shown that the 'added worker effect' decreases the risks of unemployment for single-unemployment households and male-breadwinner households in case if both children and adults are working. However, considering the fact that the 'added worker effect' is provided only by working adults, risks of unemployment potentially increase especially for single-unemployment and male-breadwinner households. The same concerns discouraged worker effect for all the types of households and, especially, for femalebreadwinner households, when risks of unemployment also increase.

The effect from full decommodification, (e.g., registration at a public employment office and receiving benefits or assistance) turned out to have important influence on decreasing unemployment risks for female-breadwinner and dual-unemployment households, while this effect has contradictory character for single-employment, single-unemployment and malebreadwinner households, when risks of unemployment are increasing. On the other hand, 
decommodification without financial support of unemployment, (e.g., without receiving benefits or assistance), potentially provides increasing risks of unemployment for dual-earner, single-employment, single-unemployment, male-breadwinner and dual-unemployment households. Risks of unemployment are decreasing for female-breadwinner households, however.

In general, when taking into account only inside-household effects, comparative analysis has shown that the difference in unemployment rate between countries and between households is higher for unemployed singles (variance of around 3.8\% and 3.5\% on unemployment rate, respectively). Dual-unemployment households are more homogeneous in terms of unemployment, because variance between households tends to be around $2.1 \%$ and within person variance (inside households) tends to be around $0.9 \%$.

In the second stage, to identify the country-level factors that explain dynamics of unemployment and the gap between types of households in terms of unemployment, we included the country-level variables and their interaction terms with the fixed-slope variables on the familialization effect and the decommodification effect in the models (individual level variables). In this part of the analysis, we were primarily interested in one fixed effect, i.e., 'time' and included the time variable to represent the period of observation from 2006 to 2016, with 2006 as the baseline. As before, the random part of the model means that the intercept (unemployment rate) varies across countries and households.

We carried out an ANOVA test in order to see whether including time-effect variable improves the model on country-level variables and their cross-level interaction with individuallevel variables. In general, based on the results of the log-likelihood test (logLik) and comparisons between Akaike information criterion (AIC) and Bayesian information criterion (BIC) indicators, the results of ANOVA test (not given here) confirmed that the cubic trend is the best choice for fitting the data and adjusting to the time factor. Therefore, unemployment is 
highly dependent on the time factor having cyclical fluctuations: 2006-2009, 2010-2013 and 2014-2016. The reduction in AIC and BIC in the last model (adjusted to the time-effect), compared to the model not adjusted to the time-effect, indicates a statistically significant improvement in the model's fit. Hereby we detail the model, which represents country-level factors of unemployment rate adjusted to the time factor as a cubic trend and includes polynomials for three time periods. Table 2 reports the results of this analysis, showing the estimates for the relevant covariates and cross-level interaction between individual-level, country-level and time-effect factors.

\section{$<$ Table 2 here $>$}

As evidence suggests, macro-economic growth and strict employment protection, through the regulation of regular and temporary contracts, potentially provides decreasing risks of unemployment for all the types of households considered in the analysis. The effect from Active Labour Market Policy (ALMP) measures, (e.g., increasing spending on ALMP programmes) provides decreasing risks of unemployment for dual-earner households. However, male-breadwinner, dual-unemployment and especially single-unemployment households potentially experience higher risks of unemployment, due to more active ALMP measures.

The results suggest that interaction between the effects from familialization and decommodification, in combination with employment protection and activation policy, can cause controversial effects for different types of households. Firstly, we find that the strict employment protection, through the regulation of regular contracts, potentially provides decreasing risks of unemployment for single-employment and female-breadwinner households, regardless of existence of familialization of care inside a household. On the contrary, the effect from strict employment protection, through the regulation of temporary contracts, potentially 
provides increasing risks of unemployment for dual-earner, male-breadwinner and dualunemployment households, when familialization of care inside a household exists.

Secondly, we find that the effect from the strict employment protection, through the regulation of regular contracts, potentially allows for decreasing risks of unemployment for all other types of households, except dual-earners. In this case, the effect from full decommodification has a positive character on dynamics of risks of unemployment in households. On the contrary, when taking into account the effect from the strict employment protection through the regulation of temporary contracts, we find that risks of unemployment are potentially increasing for all other types, except single-unemployed households. In this case, the effect from full decommodification has a positive character on the dynamics of risk of unemployment only for single-unemployed households.

Lastly, activation policy in combination with decommodification effect potentially has a more controversial effect on dynamics of unemployment. Likewise, the effect from activation policy in interaction with the effect from full decommodification causes increasing risk of unemployment for single-employment and single-unemployment households. However, risks of unemployment are potentially decreasing for male-breadwinner and dual-unemployment households. Furthermore, the effect from activation policy in interaction with the effect from partial decommodification (registration without benefits) potentially causes decreasing risks of unemployment for all the types of households.

In general, when taking into account only macro-level effects, we find that the difference in unemployment rate between countries and between households is higher for unemployed singles (variance of around $10.9 \%$ and $4.9 \%$, respectively). Dual-unemployment households are more homogeneous in terms of the unemployment rate, because variance between households tends to be around $2.5 \%$ and within person variance (inside households) tends to be around $1 \%$. To illustrate the variance in this gap across countries, we ran ANOVA 
test with Bonferroni correction for each country separately and plotted the mean of fitted values on the unemployment rate for each country in Figure 2.

\section{$<$ Figure 2 here $>$}

Figure 2 shows that the unemployment rate potentially increases, due to the influence of macro-level determinants and economic fluctuations in the former communist countries which are new EU member states, such as Latvia, Czechia, Slovenia, Slovakia, Estonia, Hungary and Poland. In contrast, in countries providing a conservative welfare state - such as Germany, France, Austria, Belgium, the Netherlands, Italy and Spain - the unemployment rate decreases due to the influence of macro-level regulation. In countries governed by a liberal regime (such as the UK), influence from macro-level regulation was more impactful, the evidence of which is a significant decrease in the unemployment rate. Again, there were clear patterns discernible in countries operating particular welfare-state regimes; the countries with above-average gaps between unemployment rates, due to influence from macro-level deregulation, are predominantly former communist, new EU member states.

To illustrate the variance in the gap across countries and households, we ran ANOVA test with Bonferroni correction for each country and each type separately and plotted the mean of fitted values on unemployment rate for each country in Figure 3.

\section{$<$ Figure 3 here $>$}

Figure 3 shows that households of Austria, Luxembourg, United Kingdom and Netherlands have the lowest gaps in the unemployment rate among the types of households and below the average rate considered for all the countries in the analysis. The countries with more significant gaps between unemployment rates for single-unemployed and other types of households are predominantly former communist new EU member states: Poland, Hungary and Slovakia. Single-unemployed households, however, have the highest unemployment rates in Estonia, Portugal, Latvia and Spain. 


\section{Discussion and Conclusion}

A key aspect of the paper is the exploration of different types of strategies that households and welfare regimes use to address the risk of unemployment. When considering inside-household effects on risks of unemployment, the research finds that the age and number of children present in a household would likely influence the labour market participation barriers and constraints experienced by households, but also impact the extent to which in-work or out-of-work welfare transfers play a role in household finances. This could be particularly important for lone-parentunemployed households. Given the fundamental differences between households with and without children, it seems justified to consider this circumstance as significant in influencing the risk of unemployment.

Furthermore, this research came to the conclusion that the presence of unemployment in a household potentially increases risks of unemployment: the discouraged worker effect has negative impact on risks of unemployment for all the types of households and especially for female-breadwinners. On the other hand, more detailed analysis has shown that the 'added worker effect' has a double-sided influence. In this case, if additional employment is provided by both working children and working adults, risks of unemployment are potentially lessened for single-unemployment and male-breadwinner households. However, when taking into account the fact that additional employment is provided only by working adults, risks of unemployment are potentially increased mostly for single-unemployed and male-breadwinners. Therefore, an additional employment serves as an important form of insurance against job and income loss due to an expected 'added worker effect' (Gush, Scott and Laurie 2015).

The factor of breadwinning has an important bearing upon analysis of familialization of care and decommodification for risks of unemployment. The research has found that familization of care has a household-specific effect versus a gender-specific effect, (e.g., it is more important for growing risks of unemployment, especially for male-breadwinner 
households). However, decommodification also has a gender-specific effect: this effect turns out to be important for decreasing risks of unemployment for female-breadwinners and has contradictory effects for male-breadwinner households.

In this respect, we find that traditional male-breadwinner model household faces higher risk of unemployment than even a female-breadwinner model. Despite obvious evidence that economic fluctuations have a great impact on the dynamics of risks of unemployment for all the types of household, the more pronounced effect is upon dual-earners and singleemployed households, while this effect is smoothed (smaller) for male- and femalebreadwinners. Therefore, our findings contradict previous research suggesting that dual-earners are more resilient in the face of external shocks, because, in our case, the breadwinner model remains more stable when confronted by external economic fluctuations.

Bryan and Longhi (2015) found having an employed partner to be an effective insurance mechanism for unemployment, because s/he can assistant the unemployed spouse's re-entry into the labour market. As Harkness and Evans (2011) argue having a partner in work may, to some extent, shelter people from the consequences of a recession by facilitating a quicker return to work if they lose their job. Another explanation is, in line with the argument of Ehlert (2013), that clearer differences in economic wellbeing after a job loss emerge for single adults, because laid-off people living in single households face higher and more enduring losses in household income.

Despite obvious evidence that breadwinners are more stable in the face of economic fluctuations, and that male-breadwinners in particular are at higher risks of unemployment (due to familialization of care, additional employment of adults in a family, the effects of decommodification and ALMP measures), we find female-breadwinners to be at greater risk of unemployment (due to discouraged worker effect, while the effect from decommodification turned out to have an important influence on lessening their unemployment risks). 
When comparing two breadwinner models, we find that these are two different strategies of unemployment behaviour. The behaviour of male-breadwinners is paradoxical, because, when still relying of familialization of care, negative influences from labour market deregulation mechanisms are still seen. On the contrary, female-breadwinners are less subject from negative influence from the familialization of care on unemployment, while labour market deregulation mechanisms help them to decrease the risk of unemployment, despite the fact that discouraged worker effect is still an important factor for increasing unemployment.

Even the meaning of labour market deregulation changes radically, depending on the gender of a breadwinner and the familialization of care. Strict employment protection, through the regulation of regular contracts, potentially provides decreasing risks of unemployment for female-breadwinner households, while the effect from the strict employment protection, through the regulation of temporary contracts, is more controversial (negative) for malebreadwinners. These conclusions could be explained by reference to insider/outsider theory, as proposed by Emmenegger (2009), who argues that labour market outsiders (unemployed, parttime and temporarily employed people) can be expected to be just as supportive of job security regulations. We infer that subjective job insecurity (Erlinghagen 2008) within households featuring unemployment arises despite important labour market and social security institutions; subjective job insecurity can be mostly explained by socio-economic and demographic individual determinants of the employment situation within households.

Male and female-breadwinners are like two sides of the same coin: while unemployment inside male-breadwinner households is intensified by labour market deregulation measures and familialization of care, unemployment inside female-breadwinner models intensifies the likelihood of the unemployment of the female-breadwinners themselves, despite the fact that labour market deregulation has a positive effect on decreasing unemployment. This conclusion can be explained by the mechanism of automatic market 
clearing through decommodification (Giersch 1985; Siebert 1997; Scarpetta 1996) with regard to both male and female unemployed.

Especially in the context of growing social polarization, divergence between countries involved in welfare state development could be explained by the second-order effects of the allocation of welfare responsibilities to the state, the market or the family, such that welfare provision may potentially result in negative incentive effects for 'unprotected' actors in society. The issue of the deregulation of unemployment risks inside households leads to a more important issue concerning the deregulation of social risks inside European societies.

The evidence suggests that the family absorbs market failures as well as the market, while the state compensates for family failures. Present-day societies seem to experience triple failure, where private risks, which families experience at the micro-level, become public issues considered at the level of state and market. It is accordingly useful to begin with an understanding of why the crisis in the contemporary welfare state has developed. The possible answer to this question could lie in understanding the changing distribution and intensity of social risks, how risks are pooled and distributed between state, market and family and why the failures of these social institutions can still produce a welfare deficit or plunge the welfare state into crisis.

\section{Bibliography}

1. Ball, L. 1999. “Aggregate Demand and Long-Run Unemployment”. Brookings Papers on Economic Activity 38: 189-251.

2. Ball, L. 2009. "Hysteresis in Unemployment: Old and New Evidence”. NBER Working papers.

3. Bande, R. and M. Karanassou. 2009. "Labour Market Flexibility and Regional Unemployment Rate Dynamics: Spain 1980-1995”. Papers in Regional Science 88(1): 3789. 
4. Bassanini, A., L. Nunziata and D. Venn. 2009. “Job Protection Legislation and Productivity Growth in OECD Countries”. Economic Policy 24(58): 349-402. https://doi.org/10.1111/j.1468-0327.2009.00221.x

5. Belot, M. J. Van Ours. 2004. "Does The Recent Success Of Some OECD Countries In Lowering Their Unemployment Rates Lie In The Clever Design Of Their Labour Market Reforms?” Oxford Economic Papers 56(4): 621-642. https://doi.org/10.1093/oep/gpf057

6. Bennett, J. and K. Möhring. 2015. “Cumulative (Dis)Advantage? The Impact of Labour Market Policies on Late Career Employment From A Life Course Perspective”. Journal of Social Policy 44(2): 213-233. https://doi.org/10.1017/S0047279414000816

7. Bennett, J. 2016. “Skill-Specific Unemployment Risks: Employment Protection and Technological Progress - A Cross-National Comparison”. Journal of European Social Policy 26(5): 402-416. https://doi.org/10.1177/0958928716664294

8. Bentolila, S. and G. Bertola. 1990. "Firing Costs and Labor Demand: How Bad Is Eurosclerosis?” Review of Economic Studies 57: 381-402.

9. Bertola, G. 1990. “Job Security, Employment, and Wages”. European Economic Review 34(4): 851-879. https://doi.org/10.1016/0014-2921(90)90066-8

10. Blanchard, O. J. and L. H. Summers. 1986. "Hysteresis and the European Unemployment Problem”. NBER Macroeconomics Annual 1: 15-78.

11. Blanchard, O. J. and L. F. Katz. 1992. “Regional Evolutions”. Brookings Papers on Economic Activity 1: 1-75.

12. Blank, R. 1994. “The Employment Strategy: Public Policies To Increase Work And Earnings”. Pp. 168-204 in Confronting Poverty, edited by S. Danziger, G. Sandifur and D. Weinberg. Cambridge, Mass: Harvard University Press.

13. Breen, R. 2005. “Explaining Cross-National Variation in Youth Unemployment: Market and Institutional Factors”. European Sociological Review 21(2): 125-134. https://doi.org/10.1093/esr/jci008

14. Bryan, M. and S. Longhi. 2015. “Getting Back Into Work after Job Loss: The Role of Partner Effects”. ISER Working Paper Series 2015-11-21, May 2015.

15. Buechtemann, C. 1993. "Employment Security and Labor Market Behavior: Interdisciplinary Approaches and International Evidence”. Labour 7(3): September 1993.

16. Card, D. and A. B. Krueger. 1995. Myth and Measurement: The New Economics of the Minimum Wage. Princeton, NJ: Princeton University Press. 
17. Carr-Hill, R. 2015. "Non-Household Populations: Implications for Measurements of Poverty Globally and In the UK”. Journal of Social Policy 44(2): 255-275. https://doi.org/10.1017/S0047279414000907

18. Clasen, J. and \& A. Koslowski. 2013. “Unemployment And Income Protection: How Do Better-Earning Households Expect To Manage Financially?” Journal of Social Policy 42(3): 587-603. https://doi.org/10.1017/S004727941300007X

19. Decressin, J. and A. Fatàs. 1995. "Regional Labour Marker Dynamics in Europe”. European Economic Review 39: 1627-1655.

20. Dolado, J., F. Kramarz, S. Machin, A. Manning, D. Margolis and C. Teulings. 1996. “The Economic Impact of Minimum Wages in Europe”. Economic Policy 11(23): 317372.

21. Ehlert, M. 2012. "Buffering Income Loss Due To Unemployment: Family and Welfare State Influences On Income after Job Loss in the United States and Western Germany”. Social Science Research 41(4): 843-860. https://doi.org/10.1016/j.ssresearch.2012.02.002

22. Ehlert, M. 2013. “Job Loss Among Rich And Poor In The United States And Germany: Who Loses More Income?” Research in Social Stratification and Mobility 32: 85-103. https://doi.org/10.1016/j.rssm.2012.11.001

23. Ehlert, M. 2015. “Couples’ Strategies after Job Loss in West Germany and the United States - The Added Worker Effect and Linked Life Courses”. Schmollers Jahrbuch 135(1): 55-65. https://doi.org/10.3790/schm.135.1.55

24. Ehlert, M. 2016. The Impact of Losing Your Job. Unemployment and Influences from Market, Family, and State on Economic Well-Being in the Us and Germany. Amsterdam: Amsterdam University Press.

25. Elhorst, J. P. 2003. “The Mystery of Regional Unemployment Differentials: Theoretical and Empirical Explanations”. Journal of Economic Surveys 17(5): 709-748.

26. Elmeskov, J., J. P. Martin and S. Scarpetta. 1998. Key Lessons for Labour Market Reforms: Evidence from OECD Countries' Experiences. Stockholm: Economic Council of Sweden.

27. Emmenegger, P. 2009. "Barriers to Entry: Insider/Outsider Politics and the Political Determinants of Job Security Regulations”. Journal of European Social Policy 19(2): 131-146. https://doi.org/10.1177/0958928708101866

28. Erlinghagen, M. 2008. "Self-Perceived Job Insecurity And Social Context: A Multi-Level Analysis of 17 European Countries”. European Sociological Review 24(2): 183-197. https://doi.org/10.1093/esr/jcm042 
29. Esping-Andersen, G. and M. Regini. 2000. Why Deregulate Labour Markets? Oxford, UK: Oxford University Press.

30. Esping-Andersen, G. 1996. Welfare States in Transition: National Adaptations in Global Economies. SAGE Publications Ltd.

31. Esping-Andersen, G. 1999. Social Foundations of Post-Industrial Economies. Oxford: Oxford University Press.

32. Esping-Andersen, G., A. Hemerijck and J. Myles. 2002. Why We Need A New Welfare State. Oxford: Oxford University Press. https://doi.org/10.1093/0199256438.001.0001

33. Estevez-Abe, M., T. Iversen and D. Soskice. 2001. "Social Protection And The Formation Of Skills: A Reinterpretation Of The Welfare State”. Pp. 83-145 in Varieties Of Capitalism: The Institutional Foundations Of Comparative Advantage, edited by P. Hall and D. Soskice. New York: Oxford University Press. https://doi.org/10.1093/0199247757.003.0004

34. Finch, W. H., J. E. Bolin and K. Kelley. 2014. Multilevel Modelling Using R. Taylor \& Francic Group: CRC Press.

35. Freeman, R. B. 2005. "Labour Market Institutions without Blinders: The Debate over Flexibility and Labour Market Performance”. International Economic Journal 19(2): 129145. https://doi.org/10.1080/10168730500080675

36. Gangl, M. 2003. “The Only Way Is Up? Employment Protection and Job Mobility among Recent Entrants to European Labour Markets”. European Sociological Review 19(5): 429449. https://doi.org/10.1093/esr/19.5.429

37. Gardiner, K. and J. Millar. 2006. "How Low-Paid Employees Avoid Poverty: An Analysis By Family Type And Household Structure”. Journal of Social Policy 35(3): 351-369. https://doi.org/10.1017/S0047279406009822

38. Gebel, M. and J. Giesecke. 2011. “Labour Market Flexibility and Inequality: The Changing Skill-Based Temporary Employment and Unemployment Risks In Europe”. Social Forces 90(1): 17-39. https://doi.org/10.1093/sf/90.1.17

39. Gebel, M. and J. Giesecke. 2016. “Does Deregulation Help? The Impact of Employment Protection Reforms on Youths’ Unemployment and Temporary Employment Risks in Europe”. European Sociological Review 32(4): 486-500. https://doi.org/10.1093/esr/jcw022

40. Giersch, H. 1985. “Eurosclerosis”. Kieler Diskussionsbeiträge, No.112, Institut für Weltwirtschaft (IfW), Kiel. 
41. Griffiths, R. 2017. "No Love on the Dole: The Influence of the UK Means-Tested Welfare System on Partnering and Family Structure”. Journal of Social Policy 46(3): 543-561. https://doi.org/10.1017/S0047279417000046

42. Gush, K., J. Scott and H. Laurie. 2015. “Households’ Responses to Spousal Job Loss: ‘All Change’ Or 'Carry On As Usual'”? Work, Employment and Society 29(5): 703-719. https://doi.org/10.1177/0950017014556411

43. Harkness, S. and M. Evans. 2011. “The Employment Effects Of Recession On Couples In The UK: Women’s And Household Employment Prospects And Partners’ Job Loss”. Journal of Social Policy 40(4): 675-693. https://doi.org/10.1017/S0047279411000201

44. Henry, B., M. Karanassou and D. Snower. 2000. “Adjustment Dynamics and the Natural Rate: An Account of UK Unemployment”. Oxford Economic Papers 52: 178-203.

45. Holmlund, B. and H. Lang. 1985. "Quit Behaviour under Imperfect Information: Searching, Moving, Learning”. Economic Inquiry 23(3): 383-393. https://doi.org/10.1111/j.1465-7295.1985.tb01774.x

46. Irwin, S. and L. Morris. 1993. "Social Security or Economic Insecurity? The Concentration of Unemployment (And Research) Within Households”. Journal of Social Policy 22(3): 349-72. https://doi.org/10.1017/S0047279400019577

47. Kahn, L. M. 2010. "Employment Protection Reforms, Employment, and the Incidence of Temporary Jobs in Europe: 1996 - 2001”. Labour Economics 17(1): 1-15. https://doi.org/10.1016/j.labeco.2009.05.001

48. Karanassou, M. and D. J. Snower. 1997. “Is The Natural Rate A Reference Point?” European Economic Review 41(3-5): 102-115.

49. Karanassou, M. and D. J. Snower. 1998. “How Labour Market Flexibility Affects Unemployment: Long-Term Implications Of The Chain Reaction Theory”. The Economic Journal 108(448): 49-61.

50. Karanassou, M. and D. J. Snower. 2000. “Characteristics of Unemployment Dynamics: The Chain Reaction Approach”. IZA Discussion Paper 127: 1-25.

51. Karanassou, M., H. Sala and P. F. Salvador. 2008a. "Capital Accumulation and Unemployment: New Insights on The Nordic Experience”. Cambridge Journal of economics 32: 977-1001.

52. Karanassou, M., H. Sala and P. F. Salvador. 2008b. “The (Ir)Relevance Of The NRU For Policy Making: The Case Of Denmark”. Scottish Journal of Political Economy 55: 369392. 
53. Kortteinen, M. and H. Tuomikoski. 1998. Työtön: Tutkimus Pitkäaikaistyöttömien Selviytymisestä/Unemployed: The Research About Surviving Of Long-Term Unemployed. Helsinki: Hanki ja Jää.

54. Kunz, M. 2009. “Unemployment Disparities In Germany - Do Districts Adjust Differently Than Larger Regional Units?” IAB-Discussion Paper 11: 2-23.

55. Layard, R. and S. Nickell. 1986. “Unemployment in Britain”. Economica 53: 121-169.

56. Layard, R., S. Nickell and R. Jackman. 1991. Unemployment: Macroeconomic Performance and the Labour Market. Oxford: Oxford University Press.

57. Lee, S. S. 2013. “Examining Policy Configurations as Conditions for Long-Term Unemployment and Non-Standard Employment in OECD Countries Using Fuzzy-Set Analysis”. Quality \& Quantity 47(6): 3521-3536. https://doi.org/10.1007/s11135-012$\underline{9737-9}$

58. Lewis, J. and D. Linzer. 2005. “Estimating Regression Models In Which The Dependent Variable Is Based On Estimates”. Political Analysis 13(4): 345-364. https://doi.org/10.1093/pan/mpi026

59. Martin, R. 1997. "Regional Unemployment Disparities and Their Dynamics”. Regional Studies 31: 237-252

60. Milner, A., L. Krnjacki, P. Butterworth and A. D. LaMontagne. 2016. “The Role Of Social Support In Protecting Mental Health When Employed And Unemployed: A Longitudinal Fixed-Effects Analysis Using 12 Annual Waves Of The HILDA Cohort”. Social Science \& Medicine 153: 20-26. https://doi.org/10.1016/j.socscimed.2016.01.050

61. Mishel, L. and J. Bernstein. 1993. State Of Working America, 1992-93. N.Y.: M.E. Sharpe.

62. Moen, P. 2003. It’s About Time: Couples And Careers. Ithaca, NY: Cornell University Press.

63. Nickell, S. 1997. “Unemployment and Labour Market Rigidities: Europe versus North America”. The Journal of Economic Perspectives 11: 55-74.

64. Nickell, S. 1998. “Unemployment: Questions and Some Answers”. The Economic Journal 108: 802-816.

65. Nickell, S., L. Nunziata and W. Ochel. 2005. "Unemployment In The OECD Since The 1960s: What Do We Know?” The Economic Journal 115(500): 1-27. https://doi.org/10.1111/j.1468-0297.2004.00958.x 
66. Pierre, G. and S. Scarpetta. 2004. "Employment Regulations through the Eyes of Employers: Do They Matter and How Do Firms Respond To Them?” Policy Research Working Papers 1: 1-27. https://doi.org/10.1596/1813-9450-3463

67. Sage, D. 2013. “Activation, Health And Well-Being: Neglected Dimensions?” International Journal of Sociology and Social Policy 33(1/2): 4-20. https://doi.org/10.1108/01443331311295145

68. Sage, D. 2015. “Do Active Labour Market Policies Promote The Well-Being, Health, And Social Capital Of The Unemployed? Evidence from the UK”. Social Indicators Research 124: 319-337. https://doi.org/10.1007/s11205-014-0788-2

69. Scarpetta, S. 1996. “Assessing the Role of Labour Market Policies and Institutional Settings on Unemployment: A Cross-Country Study”. OECD Economic Studies 26: 4398.

70. Scharpf, F. 1999. Governing In Europe: Effective And Democratic? Oxford: Oxford University Press.

71. Siebert, H. 1997. “Labor Market Rigidities: At the Root of Unemployment in Europe”. Journal of Economic Perspectives 11(3): 37-54. https://doi.org/10.1257/jep.11.3.37

72. Sjöberg, O. 2004. “The Role of Family Policy Institutions in Explaining Gender-Role Attitudes: A Comparative Multilevel Analysis of Thirteen Industrialized Countries”. Journal of European Social Policy 14(2): 107-123. https://doi.org/10.1177/0958928704042003

73. Stockhammer, E. 2004a. "Explaining European Unemployment: Testing the NAIRU Hypothesis and a Keynesian Approach”. International Review of Applied Economics 18(1): 3-23.

74. Stockhammer, E. 2004b. "Is There An Equilibrium Rate Of Unemployment In The Long Run?” Review of Political Economy 16: 59-77.

\title{
7. Annex
}

\author{
$<$ Table 1 in Annex here > \\ $<$ Table 2 in Annex here $>$ \\ $<$ Table 3 in Annex here $>$
}


Figures in the text

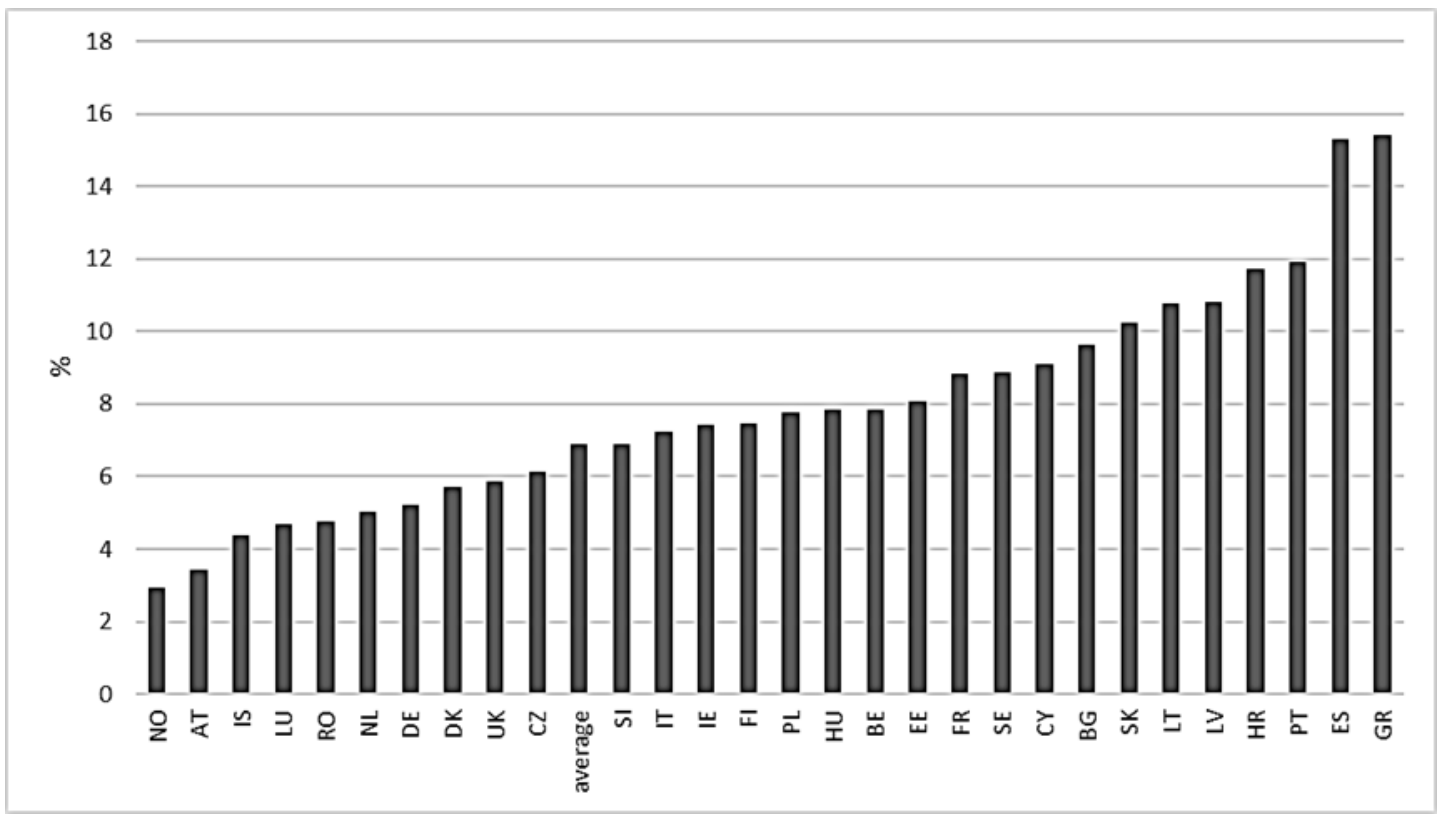

Figure 1. Mean-centred unemployment rate of the study population per country, estimated after ANOVA test with Bonferroni correction (EU-LFS, 2006-2016, N=3,006,433).

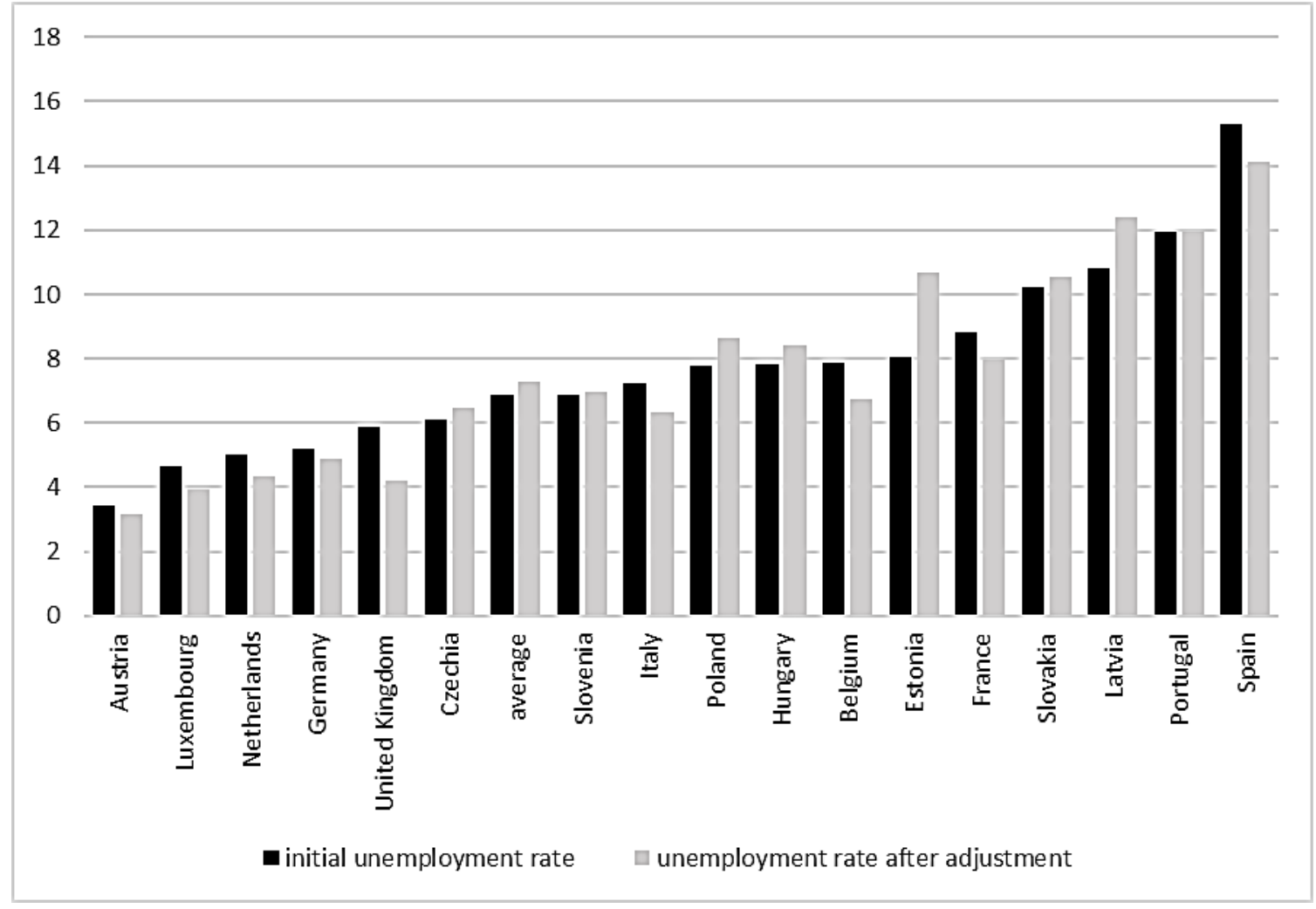

Figure 2. Mean-centred unemployment rate of the study population per country, estimated after ANOVA test with Bonferroni correction before and after adjustment to macro-level factors, as in Table 2. 


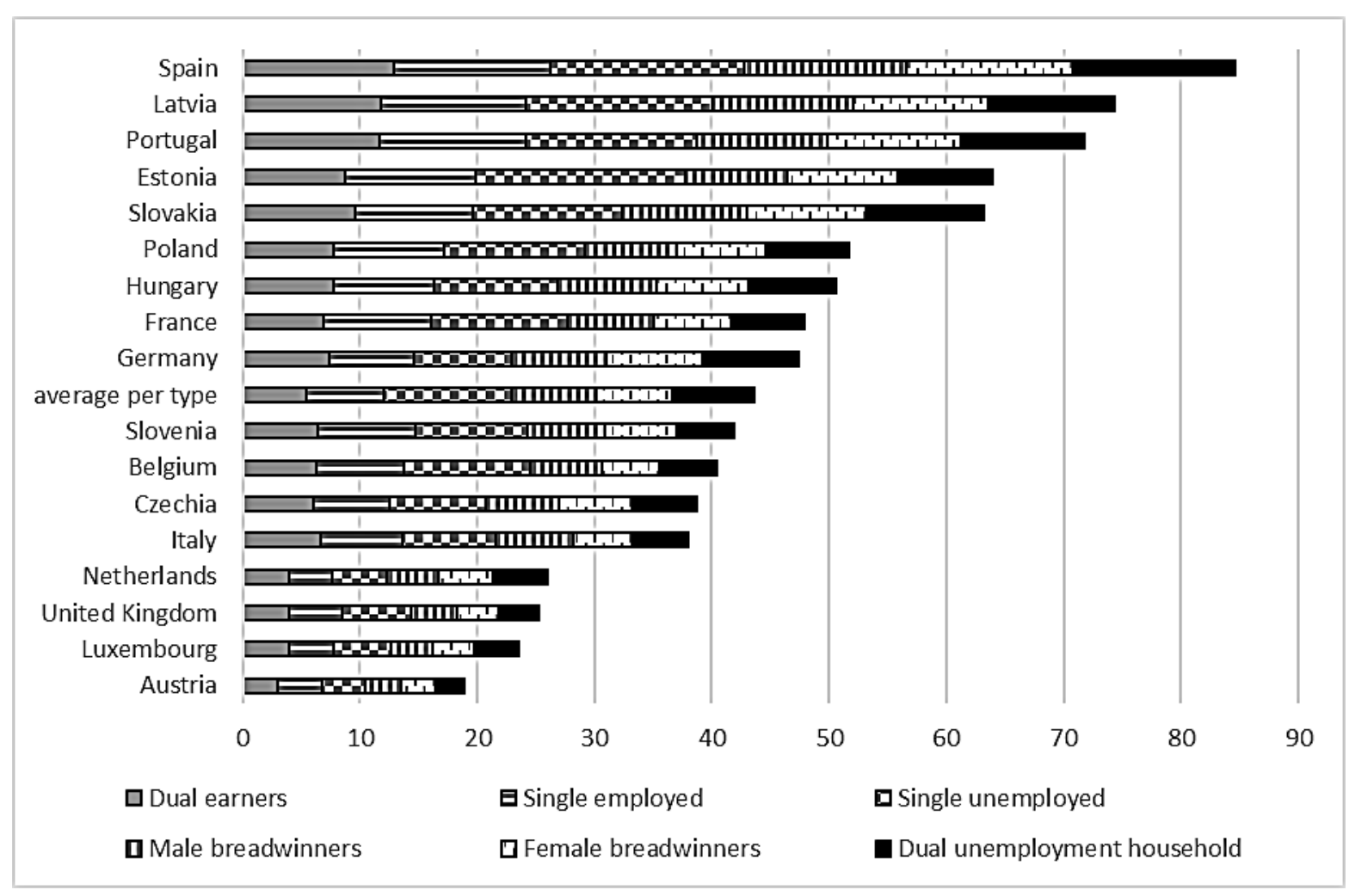

Figure 3. Mean-centred unemployment rate of the study population per country and per type of household estimated after ANOVA test with Bonferroni correction, controlled for macro-level factors, as in Table 2. 
Tables in the text:

Table 1. Linear regression models explaining unemployment rate dynamics across 17 European countries in 2006-2016 (REML)

Type 1 / model 1a, Type 2 / model 1b, Type 3 / model 1c, Type 4 / model 1d, Type 5 / model 1e, Type 6 / model 1f

\begin{tabular}{|c|c|c|c|c|c|c|}
\hline & Model 1a & Model 1b & Model 1c & Model 1d & Model 1e & Model 1f \\
\hline (Intercept) & $14.617 * * *(0.834)$ & $14.915^{* * *}(0.747)$ & $25.689 * * *(0.980)$ & $31.901^{* * *}(1.955)$ & $27.593 * * *(2.325)$ & $31.923 * * *(1.153)$ \\
\hline \multicolumn{7}{|l|}{ Age groups (ref.=15-19) } \\
\hline $20-24$ & $-2.782 * * *(0.417)$ & $-3.754 * * *(0.106)$ & $-7.949 * * *(0.100)$ & $-12.470 * * *(0.413)$ & $-8.240 * * *(0.875)$ & $-7.987 * * *(0.392)$ \\
\hline $25-29$ & $-6.901 * * *(0.416)$ & $-7.699 * * *(0.105)$ & $-12.643 * * *(0.126)$ & $-19.218 * * *(0.407)$ & $-14.033 * * *(0.863)$ & $-13.516 * * *(0.391)$ \\
\hline $30-34$ & $-9.097 * * *(0.416)$ & $-9.749 * * *(0.105)$ & $-15.269 * * *(0.129)$ & $-22.540 * * *(0.407)$ & $-16.787 * * *(0.863)$ & $-16.969 * * *(0.392)$ \\
\hline $35-39$ & $-10.617 * * *(0.416)$ & $-11.041 * * *(0.105)$ & $-16.962 * * *(0.130)$ & $-24.291 * * *(0.408)$ & $-18.441 * * *(0.863)$ & $-19.037 * * *(0.392)$ \\
\hline $40-44$ & $-11.172 * * *(0.416)$ & $-11.657 * * *(0.105)$ & $-17.869 * * *(0.127)$ & $-25.065 * * *(0.408)$ & $-19.057 * * *(0.862)$ & $-19.828 * * *(0.388)$ \\
\hline $45-49$ & $-11.474 * * *(0.416)$ & $-12.072 * * *(0.105)$ & $-18.295 * * *(0.124)$ & $-25.543 * * *(0.406)$ & $-19.618 * * *(0.860)$ & $-20.746 * * *(0.384)$ \\
\hline $50-54$ & $-11.524 * * *(0.416)$ & $-12.244 * * *(0.105)$ & $-18.380 * * *(0.121)$ & $-26.033 * * *(0.405)$ & $-20.126^{* * *}(0.859)$ & $-21.346^{* * *}(0.382)$ \\
\hline $55-59$ & $-11.200 * * *(0.416)$ & $-12.232 * * *(0.105)$ & $-18.766 * * *(0.119)$ & $-26.149 * * *(0.405)$ & $-20.395 * * *(0.858)$ & $-22.350 * * *(0.381)$ \\
\hline $60-64$ & $-11.428 * * *(0.416)$ & $-13.065 * * *(0.107)$ & $-20.332 * * *(0.118)$ & $-26.927 * * *(0.405)$ & $-21.153 * * *(0.859)$ & $-23.831 * * *(0.382)$ \\
\hline \multicolumn{7}{|l|}{ Level of education (ref.=High: Tertiary level) } \\
\hline Low: Lower secondary & $5.675^{* * *}(0.020)$ & $6.700^{* * *}(0.025)$ & $5.796 * * *(0.047)$ & $5.152 * * *(0.037)$ & $5.662 * * *(0.042)$ & $4.461^{* * *}(0.031)$ \\
\hline Medium: Upper secondary & $2.418^{* * *}(0.016)$ & $2.345^{* * *}(0.020)$ & $2.006 * * *(0.046)$ & $2.182 * * *(0.034)$ & $2.592 * * *(0.039)$ & $2.105^{* * *}(0.030)$ \\
\hline \multicolumn{7}{|l|}{ Sex (ref.=Male) } \\
\hline Female & $0.552 * * *(0.011)$ & $0.757 * * *(0.018)$ & $-0.038(0.031)$ & $0.204 * * *(0.020)$ & $-0.291 * * *(0.027)$ & $-0.707 * * *(0.016)$ \\
\hline \multicolumn{7}{|l|}{ Nationality (ref.=Native) } \\
\hline Immigrant & $0.497 * * *(0.033)$ & $0.453 * * *(0.033)$ & $0.564 * * *(0.062)$ & $0.306 * * *(0.058)$ & $0.144 *(0.072)$ & $-0.081(0.051)$ \\
\hline \multicolumn{7}{|c|}{ Presence of the children of the person in the same household (ref.=Child(ren) of the person is not in the same household) } \\
\hline Child(ren) of the person is in the same household & $-0.439 * *(0.135)$ & $-0.008(0.281)$ & $2.537 * * *(0.363)$ & $1.398(1.081)$ & $0.395(0.937)$ & $0.022(0.173)$ \\
\hline \multicolumn{7}{|c|}{$\begin{array}{l}\text { Need for care facilities. Person is looking after children or incapacitated adults and is not searching for a job or is working part time because: (ref.=There is no need for care facilities, because } \\
\text { a person is not looking after children or incapacitated adults) }\end{array}$} \\
\hline $\begin{array}{l}\text { Suitable care services for children are not available or a } \\
\text { ffordable }\end{array}$ & $0.476(0.389)$ & $0.231(0.661)$ & $1.633 *(0.691)$ & $1.035^{* *}(0.322)$ & $-0.297(0.873)$ & $1.253^{* * *}(0.276)$ \\
\hline
\end{tabular}




\begin{tabular}{|c|c|c|c|c|c|c|}
\hline $\begin{array}{l}\text { Suitable care services for ill, disabled, elderly are not a } \\
\text { vailable or affordable }\end{array}$ & $0.824(0.430)$ & $1.174(0.701)$ & $-0.162(0.446)$ & $1.523 * * *(0.268)$ & $1.295^{* *}(0.484)$ & $0.401 * *(0.151)$ \\
\hline $\begin{array}{l}\text { Suitable care services for both children and ill, disabled } \\
\text { and elderly are not available or affordable. }\end{array}$ & $0.545(0.727)$ & $0.178(1.100)$ & $1.412(1.032)$ & $2.879 * * *(0.628)$ & $0.066(0.947)$ & $0.433(0.364)$ \\
\hline $\begin{array}{l}\text { Care facilities do not influence decision for working pa } \\
\text { rt time or not searching for a job }\end{array}$ & $-0.322 * * *(0.087)$ & $0.709 * * *(0.197)$ & $0.256(0.222)$ & $0.667 * * *(0.099)$ & $-0.425 * *(0.147)$ & $-0.020(0.069)$ \\
\hline \multicolumn{7}{|c|}{ Registration at a public employment office (ref.=Person is not registered at a public employment office and does not receive benefit or assistance) } \\
\hline $\begin{array}{l}\text { Person is registered at a public employment office and } r \\
\text { eceives benefit or assistance }\end{array}$ & $0.017(0.101)$ & $0.320^{* * *(0.067)}$ & $0.437 * * *(0.057)$ & $0.853^{* * *(0.068)}$ & $-0.888 * * *(0.063)$ & $-0.518^{* * *(0.042)}$ \\
\hline $\begin{array}{l}\text { Person is registered at a public employment office but } d \\
\text { oes not receive benefit or assistance }\end{array}$ & $0.494 * * *(0.050)$ & $0.483^{* * *}(0.047)$ & $0.826 * * *(0.053)$ & $1.591 * * *(0.051)$ & $-0.356 * * *(0.058)$ & $0.608 * * *(0.041)$ \\
\hline $\begin{array}{l}\text { Person is not registered at a public employment office b } \\
\text { ut receives benefit or assistance }\end{array}$ & $0.449(0.287)$ & $0.071(0.375)$ & $0.245(0.328)$ & $0.236(0.344)$ & $-0.936 * *(0.344)$ & $-0.744 * * *(0.196)$ \\
\hline $\begin{array}{l}\text { Number of children in the household (aged less than } 15 \\
\text { years) }\end{array}$ & $-0.329(0.285)$ & $1.124(0.850)$ & $-6.364 * * *(0.308)$ & $-5.516(2.937)$ & $4.540(3.529)$ & - \\
\hline Number of persons aged 65 or older in the household & $-0.682 * * *(0.098)$ & $-0.841 * * *(0.074)$ & $-0.967 * * *(0.125)$ & $-0.271 * * *(0.059)$ & $-0.418^{* * *}(0.047)$ & $-0.175^{* * *}(0.024)$ \\
\hline $\begin{array}{l}\text { Number of children in the household (aged less than } 25 \\
\text { years) }\end{array}$ & $0.320(0.295)$ & $-1.267(0.839)$ & $1.701^{* * *}(0.192)$ & $-1.398(1.671)$ & $-3.054 *(1.289)$ & $-3.295 * * *(0.555)$ \\
\hline $\begin{array}{l}\text { Number of employed persons in the household (aged } 1 \\
5 \text { years and more) }\end{array}$ & $-1.517(0.823)$ & $-0.923(0.869)$ & $-13.285 * * *(1.461)$ & $-12.674 * * *(3.057)$ & $-1.781(3.719)$ & $0.713(1.805)$ \\
\hline $\begin{array}{l}\text { Number of employed adults in the household (aged } 15 \\
\text { years and more) }\end{array}$ & $1.871 *(0.824)$ & $1.747 *(0.869)$ & $12.621 * * *(1.471)$ & $11.175^{* *}(3.497)$ & $0.543(4.053)$ & $-0.220(1.807)$ \\
\hline $\begin{array}{l}\text { Number of unemployed adults in the household (aged } 1 \\
5 \text { years and more) }\end{array}$ & $1.645^{* * *}(0.153)$ & $3.346^{* * *(0.233)}$ & $2.386 * * *(0.096)$ & $0.185^{* * *}(0.051)$ & $7.024 * *(2.266)$ & $0.548 * * *(0.063)$ \\
\hline $\begin{array}{l}\text { Number of inactive adults in the household (aged } 15 \text { ye } \\
\text { ars and more) }\end{array}$ & $0.757 * * *(0.103)$ & $1.336 * * *(0.108)$ & $1.792 * * *(0.088)$ & - & $6.160 * *(2.265)$ & $-0.135 *(0.055)$ \\
\hline ICC empty model & 0.84 & 0.87 & 0.87 & 0.85 & 0.84 & 0.83 \\
\hline ICC full model & 0.83 & 0.87 & 0.87 & 0.84 & 0.84 & 0.84 \\
\hline logLik empty model & -622399.2 & -681006.0 & -419566.2 & -278532.7 & -160166.8 & -413132.1 \\
\hline logLik full model & -575556.7 & -619232.7 & -375473.8 & -257975.3 & -148898.4 & -387222.4 \\
\hline Between-country variance & 2.963 & 3.045 & 3.841 & 2.926 & 3.094 & 2.841 \\
\hline Between-person variance (between households) & 2.119 & 2.707 & 3.523 & 2.586 & 2.237 & 2.199 \\
\hline Within-person variance (inside households) & 0.957 & 1.037 & 1.342 & 1.114 & 0.978 & 0.955 \\
\hline $\mathrm{N}$ observations & 224413 & 221360 & 122678 & 94767 & 57215 & 149049 \\
\hline $\mathrm{N}$ households & 113401 & 221360 & 122678 & 51699 & 34084 & 97218 \\
\hline $\mathrm{N}$ countries & 17 & 17 & 17 & 17 & 17 & 17 \\
\hline
\end{tabular}

Notes: Model includes random intercepts and fixed slopes. Indicated are linear regression estimates on unemployment rate (the unstandardized beta, SE in parentheses). Countries in the analysis are: Austria, Belgium, Czechia, Germany, Estonia, Spain, France, Hungary, Italy, Luxembourg, Latvia, Netherlands, Poland, Portugal, Slovenia, Slovakia and United Kingdom.

$* * * \mathrm{p}<0.001, * * \mathrm{p}<0.01, * \mathrm{p}<0.05$ 
Table 2. Multilevel models with interactions between need for care facilities and unemployment insurance with country-level factors and time-effect factors

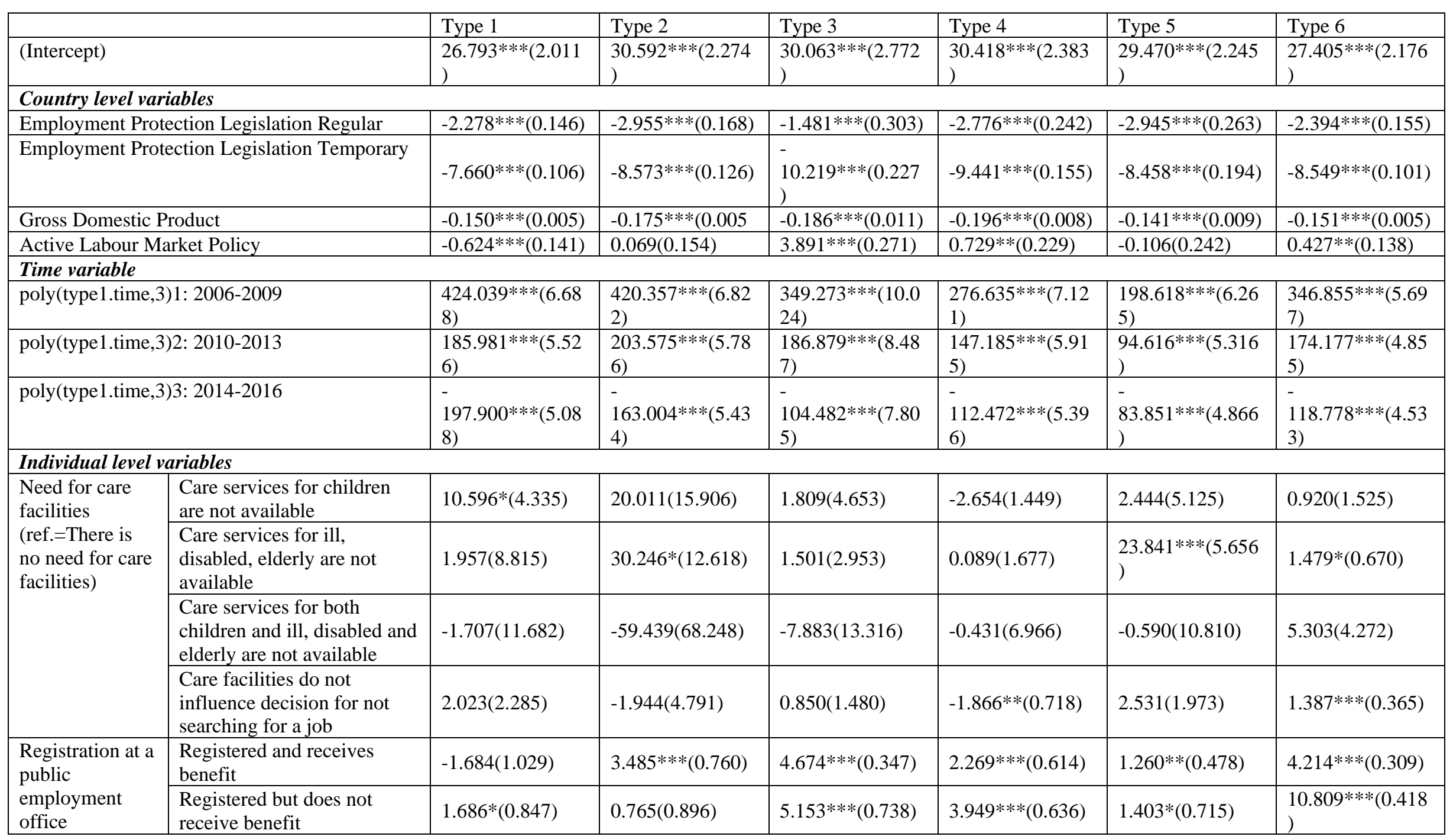




\begin{tabular}{|c|c|c|c|c|c|c|c|}
\hline $\begin{array}{l}\text { (ref.=Person is } \\
\text { not registered } \\
\text { and does not } \\
\text { receive benefit) }\end{array}$ & $\begin{array}{l}\text { Not registered but receives } \\
\text { benefit }\end{array}$ & 7.051(6.950) & $25.212 *(10.033)$ & $16.579 * *(5.828)$ & 1.945(6.363) & 6.430(6.918) & $\begin{array}{l}21.120 * * *(3.503 \\
)\end{array}$ \\
\hline \multicolumn{8}{|l|}{ Interactions } \\
\hline \multirow{4}{*}{$\begin{array}{l}\text { Employment Pr } \\
\text { otection Legislat } \\
\text { ion Regular* }\end{array}$} & $\begin{array}{l}\text { Care services for children } \\
\text { are not available }\end{array}$ & $-2.095(1.467)$ & $-5.371(5.246)$ & $-0.013(1.926)$ & $0.710(0.773)$ & $-0.424(2.039)$ & $-1.040(0.564)$ \\
\hline & $\begin{array}{l}\text { Care services for ill, } \\
\text { disabled, elderly are not } \\
\text { available }\end{array}$ & $-1.544(3.209)$ & $-11.350 * *(4.006)$ & $-1.208(1.395)$ & $0.302(0.657)$ & $-6.640 * * *(1.798)$ & $-0.522(0.357)$ \\
\hline & $\begin{array}{l}\text { Care services for both } \\
\text { children and ill, disabled and } \\
\text { elderly are not available }\end{array}$ & $-0.457(4.298)$ & $22.517(22.986)$ & $1.820(4.257)$ & $-0.725(2.429)$ & $-0.089(4.556)$ & $-1.198(1.188)$ \\
\hline & $\begin{array}{l}\text { Care facilities do not } \\
\text { influence decision for not } \\
\text { searching for a job }\end{array}$ & $0.131(0.757)$ & $0.485(1.570)$ & $-0.282(0.671)$ & $2.077 * * *(0.295)$ & $-0.910(0.702)$ & $-0.284(0.170)$ \\
\hline \multirow{4}{*}{$\begin{array}{l}\text { Employment Pr } \\
\text { otection Legislat } \\
\text { ion Temporary* }\end{array}$} & $\begin{array}{l}\text { Care services for children } \\
\text { are not available }\end{array}$ & $-0.720(0.634)$ & $-1.125(1.200)$ & $-0.773(1.307)$ & $1.510 * *(0.495)$ & $-0.365(0.919)$ & $1.555^{* *}(0.442)$ \\
\hline & $\begin{array}{l}\text { Care services for ill, } \\
\text { disabled, elderly are not } \\
\text { available }\end{array}$ & $1.565(0.856)$ & $-1.616(0.954)$ & $0.965(0.994)$ & $1.516^{* * *}(0.397)$ & $-1.035(0.721)$ & $0.802 * * *(0.218)$ \\
\hline & $\begin{array}{l}\text { Care services for both } \\
\text { children and ill, disabled and } \\
\text { elderly are not available }\end{array}$ & $2.812 *(1.232)$ & $1.534(3.044)$ & $1.610(2.563)$ & $1.003(1.719)$ & 2.201(1.530) & $0.631(0.728)$ \\
\hline & $\begin{array}{l}\text { Care facilities do not } \\
\text { influence decision for not } \\
\text { searching for a job }\end{array}$ & $-0.060(0.185)$ & $-0.192(0.372)$ & $-0.386(0.423)$ & $0.871^{* * *}(0.161)$ & $0.107(0.188)$ & $0.426 * * *(0.106)$ \\
\hline \multirow[t]{4}{*}{$\begin{array}{l}\text { Active Labour } \\
\text { Market Policy* }\end{array}$} & $\begin{array}{l}\text { Care services for children } \\
\text { are not available }\end{array}$ & $-4.660 *(1.897)$ & $-1.727(3.361)$ & 2.030(5.609) & $0.285(2.078)$ & $0.005(5.709)$ & $-0.088(1.700)$ \\
\hline & $\begin{array}{l}\text { Care services for ill, } \\
\text { disabled, elderly are not } \\
\text { available }\end{array}$ & $1.380(3.049)$ & 4.509(5.184) & $-2.857(3.981)$ & $-3.255(1.707)$ & $-4.529(2.338)$ & $-1.862 *(0.947)$ \\
\hline & $\begin{array}{l}\text { Care services for both } \\
\text { children and ill, disabled and } \\
\text { elderly are not available }\end{array}$ & $-2.092(4.354)$ & $-4.928(6.593)$ & $-0.890(8.436)$ & 6.585(5.487) & $-3.881(5.135)$ & $-3.926(2.334)$ \\
\hline & $\begin{array}{l}\text { Care facilities do not } \\
\text { influence decision for not } \\
\text { searching for a job }\end{array}$ & $-2.284 * * *(0.508)$ & $0.278(1.124)$ & $-0.467(1.438)$ & $-4.671 * * *(0.494)$ & $-0.370(0.782)$ & $-1.274 * * *(0.334)$ \\
\hline
\end{tabular}




\begin{tabular}{|c|c|c|c|c|c|c|c|}
\hline \multirow{3}{*}{$\begin{array}{l}\text { Employment Pr } \\
\text { otection Legislat } \\
\text { ion Regular* }\end{array}$} & $\begin{array}{l}\text { Registered and receives } \\
\text { benefit }\end{array}$ & $-0.297(0.349)$ & $-3.740^{* * *}(0.308)$ & $-2.333^{* * *}(0.156)$ & $-1.075^{* * *}(0.213)$ & $-0.815^{* * *}(0.173)$ & $-1.438 * * *(0.112)$ \\
\hline & $\begin{array}{l}\text { Registered but does not } \\
\text { receive benefit }\end{array}$ & $-0.361(0.268)$ & $-0.266(0.290)$ & $-0.810 * * *(0.240)$ & $-0.933^{* * *}(0.204)$ & $-0.446(0.231)$ & $-2.529 * * *(0.138)$ \\
\hline & $\begin{array}{l}\text { Not registered but receives } \\
\text { benefit }\end{array}$ & $-2.733(2.085)$ & $-6.704 *(3.121)$ & $-3.487(2.042)$ & $-0.222(2.038)$ & $-1.089(2.277)$ & $-5.784 * * *(1.140)$ \\
\hline \multirow{3}{*}{$\begin{array}{l}\text { Employment Pr } \\
\text { otection Legislat } \\
\text { ion Temporary* }\end{array}$} & $\begin{array}{l}\text { Registered and receives } \\
\text { benefit }\end{array}$ & $0.768 * * *(0.129)$ & $-0.039(0.104)$ & $-0.568 * * *(0.075)$ & $1.767 * * *(0.091)$ & $0.342 * * *(0.078)$ & $0.491^{* * *}(0.051)$ \\
\hline & $\begin{array}{l}\text { Registered but does not } \\
\text { receive benefit }\end{array}$ & $0.954 * * *(0.081)$ & $1.331 * * *(0.078)$ & $0.385 * * *(0.083)$ & $1.666 * * *(0.077)$ & $0.324 * * *(0.086)$ & $0.278^{* * *}(0.056)$ \\
\hline & $\begin{array}{l}\text { Not registered but receives } \\
\text { benefit }\end{array}$ & $1.168(0.699)$ & $-1.242(0.984)$ & $-2.593 * *(0.859)$ & $-0.023(0.871)$ & $-0.786(0.747)$ & $-1.016 *(0.410)$ \\
\hline \multirow[t]{3}{*}{$\begin{array}{l}\text { Active Labour } \\
\text { Market Policy* }\end{array}$} & $\begin{array}{l}\text { Registered and receives } \\
\text { benefit }\end{array}$ & $1.109(0.726)$ & $7.963 * * *(0.613)$ & $2.757 * * *(0.359)$ & $-2.840 * * *(0.409)$ & $-0.218(0.344)$ & $-1.247 * * *(0.233)$ \\
\hline & $\begin{array}{l}\text { Registered but does not } \\
\text { receive benefit }\end{array}$ & $-2.141^{* * *}(0.262)$ & $-1.546^{* * *}(0.263)$ & $-3.636^{* * *}(0.250)$ & $-3.265 * * *(0.228)$ & $-0.519 *(0.255)$ & $-3.980 * * *(0.167)$ \\
\hline & $\begin{array}{l}\text { Not registered but receives } \\
\text { benefit }\end{array}$ & $-2.815(3.186)$ & $-8.221(4.584)$ & $-5.701(3.338)$ & $-0.288(3.706)$ & $-3.504(3.358)$ & $-6.806^{* * *}(1.913)$ \\
\hline \multicolumn{2}{|c|}{ Between-country variance } & 8.137 & 9.210 & 10.981 & 9.502 & 8.832 & \begin{tabular}{|l|}
8.823 \\
\end{tabular} \\
\hline \multirow{2}{*}{\multicolumn{2}{|c|}{$\begin{array}{l}\text { Between-person variance (between households) } \\
\text { Within-person variance (inside households) }\end{array}$}} & 2.666 & 3.413 & 4.911 & 3.250 & 2.758 & 2.567 \\
\hline & & 1.128 & 1.293 & 1.854 & 1.272 & 1.126 & 1.046 \\
\hline \multicolumn{2}{|l|}{ logLik } & -612362.5 & -670285.2 & \begin{tabular}{|l|l|}
-416081 \\
\end{tabular} & -270850.4 & $\begin{array}{l}-157042.7 \\
\end{array}$ & -400908.5 \\
\hline
\end{tabular}

Notes: Model includes random intercepts and fixed slopes for individual level- and country-level variables. Indicated are linear regression estimates on unemployment rate (th e unstandardized beta, SE in parentheses). EPL, GDP rate and ALMP have been mean-centered. Countries in the analysis are: Austria, Belgium, Czechia, Germany, Estonia, S pain, France, Hungary, Italy, Luxembourg, Latvia, Netherlands, Poland, Portugal, Slovenia, Slovakia and United Kingdom.

*** $\mathrm{p}<0.001, * * \mathrm{p}<0.01,{ }^{*} \mathrm{p}<0.05$ 
Tables in the Annex:

Annex. Table 1. Distribution of the sample based on type of household and countries of

Europe.

\begin{tabular}{|c|c|c|c|c|c|c|c|c|c|c|c|c|c|c|}
\hline \multirow[t]{2}{*}{ Country } & \multicolumn{2}{|c|}{$\begin{array}{l}\text { Type 1: } \\
\text { couple, both } \\
\text { employed }\end{array}$} & \multicolumn{2}{|c|}{$\begin{array}{l}\text { Type 2: } \\
\text { single, } \\
\text { employed }\end{array}$} & \multicolumn{2}{|c|}{$\begin{array}{l}\text { Type 3: } \\
\text { single, not } \\
\text { employed }\end{array}$} & \multicolumn{2}{|c|}{$\begin{array}{l}\text { Type 4: } \\
\text { couple, male } \\
\text { employed }\end{array}$} & \multicolumn{2}{|c|}{$\begin{array}{l}\text { Type 5: } \\
\text { couple, } \\
\text { female } \\
\text { employed }\end{array}$} & \multicolumn{2}{|c|}{$\begin{array}{l}\text { Type 6: } \\
\text { couple, } \\
\text { neither } \\
\text { partner is } \\
\text { employed }\end{array}$} & \multicolumn{2}{|l|}{ Total } \\
\hline & Freq. & $\%$ & Freq. & $\%$ & Freq. & $\%$ & Freq. & $\%$ & Freq. & $\%$ & Freq. & $\%$ & Freq. & $\%$ \\
\hline Austria & 8,730 & $\begin{array}{l}26.0 \\
8 \\
\end{array}$ & $\begin{array}{l}10,82 \\
5 \\
\end{array}$ & $\begin{array}{l}32.3 \\
4 \\
\end{array}$ & 4,504 & $\begin{array}{l}13.4 \\
6 \\
\end{array}$ & 2,306 & 6.89 & 1,954 & 5.84 & 5,152 & $\begin{array}{l}15.3 \\
9 \\
\end{array}$ & 33,471 & $\begin{array}{l}100 . \\
00\end{array}$ \\
\hline Belgium & 482 & $\begin{array}{l}14.4 \\
4 \\
\end{array}$ & 1,192 & $\begin{array}{l}35.7 \\
1\end{array}$ & 848 & $\begin{array}{l}25.4 \\
0 \\
\end{array}$ & 201 & 6.02 & 126 & 3.77 & 489 & $\begin{array}{l}14.6 \\
5 \\
\end{array}$ & 3,338 & $\begin{array}{l}100 . \\
00\end{array}$ \\
\hline Bulgaria & $\begin{array}{l}17,99 \\
0 \\
\end{array}$ & $\begin{array}{l}29.7 \\
6 \\
\end{array}$ & 9,293 & $\begin{array}{l}15.3 \\
8 \\
\end{array}$ & 8,733 & $\begin{array}{l}14.4 \\
5 \\
\end{array}$ & 5,961 & 9.86 & 6,516 & $\begin{array}{l}10.7 \\
8 \\
\end{array}$ & $\begin{array}{l}11,94 \\
9 \\
\end{array}$ & $\begin{array}{l}19.7 \\
7 \\
\end{array}$ & 60,442 & $\begin{array}{l}100 . \\
00\end{array}$ \\
\hline Cyprus & 2,368 & $\begin{array}{l}32.6 \\
1 \\
\end{array}$ & 1,475 & $\begin{array}{l}20.3 \\
1 \\
\end{array}$ & 744 & $\begin{array}{l}10.2 \\
5 \\
\end{array}$ & 985 & $\begin{array}{l}13.5 \\
6 \\
\end{array}$ & 403 & 5.55 & 1,287 & $\begin{array}{l}17.7 \\
2 \\
\end{array}$ & 7,262 & $\begin{array}{l}100 . \\
00\end{array}$ \\
\hline Czechia & $\begin{array}{l}20,60 \\
4 \\
\end{array}$ & $\begin{array}{l}29.8 \\
5 \\
\end{array}$ & $\begin{array}{l}14,95 \\
5 \\
\end{array}$ & $\begin{array}{l}21.6 \\
7 \\
\end{array}$ & 8,024 & $\begin{array}{l}11.6 \\
2 \\
\end{array}$ & 7,414 & $\begin{array}{l}10.7 \\
4 \\
\end{array}$ & 4,910 & 7.11 & $\begin{array}{l}13,12 \\
1 \\
\end{array}$ & $\begin{array}{l}19.0 \\
1 \\
\end{array}$ & 69,028 & $\begin{array}{l}100 . \\
00\end{array}$ \\
\hline Germany & $\begin{array}{l}190,5 \\
36 \\
\end{array}$ & $\begin{array}{l}29.1 \\
2 \\
\end{array}$ & $\begin{array}{l}237,9 \\
88 \\
\end{array}$ & $\begin{array}{l}36.3 \\
7 \\
\end{array}$ & $\begin{array}{l}82,68 \\
6 \\
\end{array}$ & $\begin{array}{l}12.6 \\
4 \\
\end{array}$ & $\begin{array}{l}51,57 \\
5 \\
\end{array}$ & 7.88 & $\begin{array}{l}43,00 \\
7 \\
\end{array}$ & 57 & $\begin{array}{l}48,51 \\
3 \\
\end{array}$ & 7.41 & $\begin{array}{l}654,30 \\
5 \\
\end{array}$ & $\begin{array}{l}100 . \\
00\end{array}$ \\
\hline Denmark & $\begin{array}{l}191,9 \\
86\end{array}$ & $\begin{array}{l}53.4 \\
5 \\
\end{array}$ & $\begin{array}{l}71,39 \\
0\end{array}$ & $\begin{array}{l}19.8 \\
7 \\
\end{array}$ & $\begin{array}{l}38,55 \\
7 \\
\end{array}$ & $\begin{array}{l}10.7 \\
3 \\
\end{array}$ & 7,706 & 2.15 & 7,442 & 2.07 & $\begin{array}{l}42,12 \\
3 \\
\end{array}$ & $\begin{array}{l}11.7 \\
3 \\
\end{array}$ & $\begin{array}{l}359,20 \\
4\end{array}$ & $\begin{array}{l}100 . \\
00\end{array}$ \\
\hline Estonia & 1,910 & $\begin{array}{l}34.3 \\
3 \\
\end{array}$ & 1,452 & $\begin{array}{l}26.1 \\
0 \\
\end{array}$ & 764 & $\begin{array}{l}13.7 \\
3 \\
\end{array}$ & 452 & 8.12 & 440 & 7.91 & 546 & 9.81 & 5,564 & $\begin{array}{l}100 . \\
00\end{array}$ \\
\hline Spain & $\begin{array}{l}27,46 \\
4 \\
\end{array}$ & $\begin{array}{l}22.1 \\
9 \\
\end{array}$ & $\begin{array}{l}28,39 \\
3 \\
\end{array}$ & $\begin{array}{l}22.9 \\
4 \\
\end{array}$ & $\begin{array}{l}15,10 \\
9 \\
\end{array}$ & $\begin{array}{l}12.2 \\
1 \\
\end{array}$ & $\begin{array}{l}18,83 \\
0 \\
\end{array}$ & $\begin{array}{l}15.2 \\
1 \\
\end{array}$ & 9,902 & 8.00 & $\begin{array}{l}24,07 \\
0 \\
\end{array}$ & $\begin{array}{l}19.4 \\
5 \\
\end{array}$ & $\begin{array}{l}123,76 \\
8\end{array}$ & $\begin{array}{l}100 . \\
00\end{array}$ \\
\hline Finland & $\begin{array}{l}34,46 \\
8 \\
\end{array}$ & $\begin{array}{l}27.7 \\
8 \\
\end{array}$ & $\begin{array}{l}34,36 \\
5 \\
\end{array}$ & $\begin{array}{l}27.7 \\
0 \\
\end{array}$ & $\begin{array}{l}22,57 \\
0 \\
\end{array}$ & $\begin{array}{l}18.1 \\
9 \\
\end{array}$ & 8,706 & 7.02 & $\begin{array}{l}12,24 \\
6\end{array}$ & 9.87 & $\begin{array}{l}11,71 \\
9 \\
\end{array}$ & 9.45 & $\begin{array}{l}124,07 \\
4 \\
\end{array}$ & $\begin{array}{l}100 . \\
00\end{array}$ \\
\hline Fran & $\begin{array}{l}22,14 \\
2 \\
\end{array}$ & $\begin{array}{l}19.7 \\
9 \\
\end{array}$ & $\begin{array}{l}33,09 \\
0 \\
\end{array}$ & $\begin{array}{l}29.5 \\
8 \\
\end{array}$ & $\begin{array}{l}20,07 \\
8\end{array}$ & $\begin{array}{l}17.9 \\
5 \\
\end{array}$ & 8,060 & 7.20 & 8,249 & .37 & $\begin{array}{l}20,25 \\
4 \\
\end{array}$ & $\begin{array}{l}18.1 \\
0\end{array}$ & $\begin{array}{l}111,87 \\
3\end{array}$ & $\begin{array}{l}100 . \\
00\end{array}$ \\
\hline Greece & $\begin{array}{l}10,69 \\
8\end{array}$ & $\begin{array}{l}22.6 \\
9 \\
\end{array}$ & 8,066 & $\begin{array}{l}17.1 \\
1\end{array}$ & 7,842 & $\begin{array}{l}16.6 \\
3 \\
\end{array}$ & 6,436 & $\begin{array}{l}13.6 \\
5 \\
\end{array}$ & 3,240 & 6.87 & $\begin{array}{l}10,86 \\
3\end{array}$ & $\begin{array}{l}23.0 \\
4 \\
\end{array}$ & 47,145 & $\begin{array}{l}100 . \\
00\end{array}$ \\
\hline Croatia & 1,596 & $\begin{array}{l}27.3 \\
1 \\
\end{array}$ & 817 & $\begin{array}{l}13.9 \\
8 \\
\end{array}$ & 959 & $\begin{array}{l}16.4 \\
1 \\
\end{array}$ & 562 & 9.62 & 452 & 7.73 & 1,458 & $\begin{array}{l}24.9 \\
5 \\
\end{array}$ & 5,844 & $\begin{array}{l}100 . \\
00\end{array}$ \\
\hline Hun & 9,250 & $\begin{array}{l}21.7 \\
9 \\
\end{array}$ & 7,874 & $\begin{array}{l}18.5 \\
5 \\
\end{array}$ & 7,593 & $\begin{array}{l}17.8 \\
9 \\
\end{array}$ & 3,081 & 7.26 & 3,509 & 8.27 & $\begin{array}{l}11,14 \\
0 \\
\end{array}$ & $\begin{array}{l}26.2 \\
4 \\
\end{array}$ & 42,447 & $\begin{array}{l}100 . \\
00\end{array}$ \\
\hline Ireland & $\begin{array}{l}16,57 \\
2\end{array}$ & $\begin{array}{l}29.0 \\
8 \\
\end{array}$ & $\begin{array}{l}14,69 \\
4 \\
\end{array}$ & $\begin{array}{l}25.7 \\
8 \\
\end{array}$ & 8,357 & $\begin{array}{l}14.6 \\
6 \\
\end{array}$ & 6,732 & $\begin{array}{l}11.8 \\
1 \\
\end{array}$ & 3,487 & 6.12 & 7,146 & $\begin{array}{l}12.5 \\
4 \\
\end{array}$ & 56,988 & $\begin{array}{l}100 . \\
00\end{array}$ \\
\hline Icelan & $\begin{array}{l}26,18 \\
6 \\
\end{array}$ & $\begin{array}{l}60.5 \\
1 \\
\end{array}$ & 9,192 & $\begin{array}{l}21.2 \\
4 \\
\end{array}$ & 3,359 & 7.76 & 818 & 1.89 & 8 & 1.89 & 898 & 6.70 &, 272 & $\begin{array}{l}100 . \\
00\end{array}$ \\
\hline Italy & $\begin{array}{l}45,00 \\
2 \\
\end{array}$ & $\begin{array}{l}22.1 \\
1 \\
\end{array}$ & $\begin{array}{l}55,43 \\
9 \\
\end{array}$ & $\begin{array}{l}27.2 \\
4 \\
\end{array}$ & $\begin{array}{l}27,00 \\
0 \\
\end{array}$ & $\begin{array}{l}13.2 \\
7 \\
\end{array}$ & $\begin{array}{l}23,03 \\
1\end{array}$ & $\begin{array}{l}11.3 \\
2 \\
\end{array}$ & $\begin{array}{l}11,45 \\
0\end{array}$ & 5.63 & $\begin{array}{l}1,58 \\
3 \\
\end{array}$ & $\begin{array}{l}20.4 \\
3 \\
\end{array}$ & $\begin{array}{l}203,50 \\
5 \\
\end{array}$ & $\begin{array}{l}100 . \\
00\end{array}$ \\
\hline Lithuania & 8,974 & $\begin{array}{l}39.4 \\
4 \\
\end{array}$ & 3,869 & $\begin{array}{l}17.0 \\
1 \\
\end{array}$ & 3,112 & $\begin{array}{l}13.6 \\
8 \\
\end{array}$ & 1,860 & 8.18 & 1,744 & 7.67 & 3,193 & $\begin{array}{l}14.0 \\
3 \\
\end{array}$ & 22,752 & $\begin{array}{l}100 . \\
00\end{array}$ \\
\hline $\begin{array}{l}\text { Luxembo } \\
\text { urg }\end{array}$ & 7,148 & $\begin{array}{l}22.5 \\
6 \\
\end{array}$ & 9,920 & $\begin{array}{l}31.3 \\
2 \\
\end{array}$ & 4,514 & $\begin{array}{l}14.2 \\
5 \\
\end{array}$ & 2,686 & 8.48 & 1,794 & 5.66 & 5,616 & $\begin{array}{l}17.7 \\
3 \\
\end{array}$ & 31,678 & $\begin{array}{l}100 . \\
00\end{array}$ \\
\hline Latvia & 5,240 & $\begin{array}{l}31.4 \\
0 \\
\end{array}$ & 4,014 & $\begin{array}{l}24.0 \\
5 \\
\end{array}$ & 2,674 & $\begin{array}{l}16.0 \\
2 \\
\end{array}$ & 1,309 & 7.84 & 1,301 & 7.80 & 2,149 & $\begin{array}{l}12.8 \\
8 \\
\end{array}$ & 16,687 & $\begin{array}{l}100 . \\
00\end{array}$ \\
\hline $\begin{array}{l}\text { Netherlan } \\
\text { ds }\end{array}$ & $\begin{array}{l}65,25 \\
6 \\
\end{array}$ & $\begin{array}{l}30.7 \\
5 \\
\end{array}$ & $\begin{array}{l}56,74 \\
2 \\
\end{array}$ & $\begin{array}{l}26.7 \\
4 \\
\end{array}$ & $\begin{array}{l}22,66 \\
5 \\
\end{array}$ & $\begin{array}{l}10.6 \\
8 \\
\end{array}$ & $\begin{array}{l}26,79 \\
6 \\
\end{array}$ & $\begin{array}{l}12.6 \\
3 \\
\end{array}$ & $\begin{array}{l}15,11 \\
0\end{array}$ & 7.12 & $\begin{array}{l}25,62 \\
9 \\
\end{array}$ & $\begin{array}{l}12.0 \\
8 \\
\end{array}$ & $\begin{array}{l}212,19 \\
8 \\
\end{array}$ & $\begin{array}{l}100 . \\
00\end{array}$ \\
\hline Norway & $\begin{array}{l}26,83 \\
8 \\
\end{array}$ & $\begin{array}{l}26.2 \\
2 \\
\end{array}$ & $\begin{array}{l}48,76 \\
6 \\
\end{array}$ & $\begin{array}{l}47.6 \\
4 \\
\end{array}$ & $\begin{array}{l}14,21 \\
2 \\
\end{array}$ & $\begin{array}{l}13.8 \\
8 \\
\end{array}$ & 6,044 & 5.90 & 3,740 & 3.65 & 2,759 & 2.70 & $\begin{array}{l}102,35 \\
9 \\
\end{array}$ & $\begin{array}{l}100 . \\
00\end{array}$ \\
\hline Poland & $\begin{array}{l}18,93 \\
2\end{array}$ & $\begin{array}{l}27.2 \\
3 \\
\end{array}$ & $\begin{array}{l}10,21 \\
5 \\
\end{array}$ & $\begin{array}{l}14.6 \\
9 \\
\end{array}$ & $\begin{array}{l}10,43 \\
9\end{array}$ & $\begin{array}{l}15.0 \\
1 \\
\end{array}$ & 8,549 & $\begin{array}{l}12.2 \\
9 \\
\end{array}$ & 5,362 & 7.71 & $\begin{array}{l}16,03 \\
7 \\
\end{array}$ & $\begin{array}{l}23.0 \\
6 \\
\end{array}$ & 69,534 & $\begin{array}{l}100 . \\
00\end{array}$ \\
\hline Portugal & 5,010 & $\begin{array}{l}26.1 \\
2 \\
\end{array}$ & 4,051 & $\begin{array}{l}21.1 \\
2 \\
\end{array}$ & 2,417 & $\begin{array}{l}12.6 \\
0 \\
\end{array}$ & 2,194 & $\begin{array}{l}11.4 \\
4 \\
\end{array}$ & 1,618 & 8.43 & 3,893 & $\begin{array}{l}20.2 \\
9 \\
\end{array}$ & 19,183 & $\begin{array}{l}100 . \\
00\end{array}$ \\
\hline Romania & $\begin{array}{l}21,02 \\
8\end{array}$ & $\begin{array}{l}30.7 \\
8 \\
\end{array}$ & $\begin{array}{l}11,18 \\
4\end{array}$ & $\begin{array}{l}16.3 \\
7 \\
\end{array}$ & 8,907 & $\begin{array}{l}13.0 \\
4 \\
\end{array}$ & 7,732 & $\begin{array}{l}11.3 \\
2 \\
\end{array}$ & 3,568 & 5.22 & $\begin{array}{l}15,88 \\
8\end{array}$ & $\begin{array}{l}23.2 \\
6 \\
\end{array}$ & 68,307 & $\begin{array}{l}100 . \\
00\end{array}$ \\
\hline Sweden & $\begin{array}{l}118,6 \\
36 \\
\end{array}$ & $\begin{array}{l}41.3 \\
9 \\
\end{array}$ & $\begin{array}{l}95,37 \\
2 \\
\end{array}$ & $\begin{array}{l}33.2 \\
8 \\
\end{array}$ & $\begin{array}{l}43,43 \\
4 \\
\end{array}$ & $\begin{array}{l}15.1 \\
5 \\
\end{array}$ & 2,531 & 0.88 & 2,539 & 0.89 & $\begin{array}{l}24,10 \\
3 \\
\end{array}$ & 8.41 & $\begin{array}{l}286,61 \\
5 \\
\end{array}$ & $\begin{array}{l}100 . \\
00\end{array}$ \\
\hline Slovenia & 8,384 & $\begin{array}{l}40.8 \\
2 \\
\end{array}$ & 3,242 & $\begin{array}{l}15.7 \\
8 \\
\end{array}$ & 2,471 & $\begin{array}{l}12.0 \\
3 \\
\end{array}$ & 1,071 & 5.21 & 1,118 & 5.44 & 4,253 & $\begin{array}{l}20.7 \\
1 \\
\end{array}$ & 20,539 & $\begin{array}{l}100 . \\
00\end{array}$ \\
\hline
\end{tabular}




\begin{tabular}{|l|l|l|l|l|l|l|l|l|l|l|l|l|l|l|}
\hline Slovakia & 3,672 & $\begin{array}{l}25.7 \\
4\end{array}$ & 2,116 & $\begin{array}{l}14.8 \\
3\end{array}$ & 1,768 & $\begin{array}{l}12.3 \\
9\end{array}$ & 1,567 & $\begin{array}{l}10.9 \\
8\end{array}$ & 1,137 & 7.97 & 4,006 & $\begin{array}{l}28.0 \\
8\end{array}$ & 14,266 & $\begin{array}{l}100 . \\
00\end{array}$ \\
\hline UK & 62,96 & 33.0 & 50,34 & 26.3 & 25,68 & 13.4 & 19,52 & 10.2 & 11,05 & 5.79 & 21,21 & 11.1 \\
& 6 & 0 & 3 & 9 & 2 & 6 & 4 & 3 & 4 & 190,78 & 100. \\
5 & 2 \\
0 & 980,0 & 32.6 & 840,3 & 27.9 & 400,0 & 13.3 & 234,7 & 7.81 & $\begin{array}{l}168,2 \\
37\end{array}$ & 5.60 & $\begin{array}{l}383,0 \\
53\end{array}$ & $\begin{array}{l}12.7 \\
4\end{array}$ & $\begin{array}{l}3,006,4 \\
33\end{array}$ & $\begin{array}{l}100 . \\
00\end{array}$ \\
\hline
\end{tabular}

Table 2 in the Annex. Summary statistics of categorical variables

\begin{tabular}{|c|c|c|}
\hline & Freq. & Percent \\
\hline \multicolumn{3}{|l|}{ Nationality } \\
\hline Native & $2,820,066$ & 93.80 \\
\hline Immigrant & 186,367 & 6.20 \\
\hline Total & $3,006,433$ & 100.00 \\
\hline \multicolumn{3}{|l|}{ Age } \\
\hline $15-19$ & 80,482 & 2.68 \\
\hline $20-24$ & 153,061 & 5.09 \\
\hline $25-29$ & 209,530 & 6.97 \\
\hline $30-34$ & 225,963 & 7.52 \\
\hline $35-39$ & 215,881 & 7.18 \\
\hline $40-44$ & 230,923 & 7.68 \\
\hline $45-49$ & 292,760 & 9.74 \\
\hline $50-54$ & 408,841 & 13.60 \\
\hline $55-59$ & 551,501 & 18.34 \\
\hline $60-64$ & 637,491 & 21.20 \\
\hline Total & $3,006,433$ & 100.00 \\
\hline \multicolumn{3}{|l|}{ Education } \\
\hline High: Tertiary level & 782,610 & 27.26 \\
\hline Low: Lower secondary & 827,740 & 28.84 \\
\hline Medium: Upper secondary & $1,260,143$ & 43.90 \\
\hline Total & $2,870,493$ & 100.00 \\
\hline \multicolumn{3}{|l|}{ Sex } \\
\hline Male & $1,471,235$ & 48.94 \\
\hline Female & $1,535,198$ & 51.06 \\
\hline Total & $3,006,433$ & 100.00 \\
\hline \multicolumn{3}{|l|}{ Presence of the children of the person in the same household } \\
\hline Child(ren) of the person is in the same household & 13,684 & 0.66 \\
\hline Child(ren) of the person is not in the same household & $2,070,239$ & 99.34 \\
\hline Total & $2,083,923$ & 100.00 \\
\hline \multicolumn{3}{|l|}{ Person is not searching for a job or is working part time because: } \\
\hline Suitable care services for children are not available or affordable & 2,582 & 0.09 \\
\hline Suitable care services for ill, disabled, elderly are not available or affordable & 2,253 & 0.08 \\
\hline $\begin{array}{l}\text { Suitable care services for both children and ill, disabled and elderly are not } \\
\text { available or affordable. }\end{array}$ & 471 & 0.02 \\
\hline $\begin{array}{l}\text { Care facilities do not influence decision for working part time or not searching } \\
\text { for a job }\end{array}$ & 27,789 & 0.93 \\
\hline $\begin{array}{l}\text { There is no need for care facilities, because a person is not looking after } \\
\text { children or incapacitated adults. }\end{array}$ & $2,968,587$ & 98.90 \\
\hline Total & $3,001,682$ & 100.00 \\
\hline \multicolumn{3}{|l|}{ Registration at a public employment office } \\
\hline $\begin{array}{l}\text { Person is registered at a public employment office and receives benefit or } \\
\text { assistance }\end{array}$ & 110,519 & 4.41 \\
\hline $\begin{array}{l}\text { Person is registered at a public employment office but does not receive benefit } \\
\text { or assistance }\end{array}$ & 96,592 & 3.85 \\
\hline
\end{tabular}




\begin{tabular}{|l|l|l|}
\hline $\begin{array}{l}\text { Person is not registered at a public employment office but receives benefit or } \\
\text { assistance }\end{array}$ & 5,811 & 0.23 \\
\hline $\begin{array}{l}\text { Person is not registered at a public employment office and does not receive } \\
\text { benefit or assistance }\end{array}$ & $2,294,843$ & 91.51 \\
\hline Total & $\mathbf{2 , 5 0 7 , 7 6 5}$ & $\mathbf{1 0 0 . 0 0}$ \\
\hline
\end{tabular}

Table 3 in the Annex. Summary statistics of numerical variables

\begin{tabular}{|l|l|l|l|l|l|}
\hline Variable & $\boldsymbol{N}$ & $\begin{array}{l}\text { Mea } \\
\text { n }\end{array}$ & $\begin{array}{l}\text { Std. } \\
\text { Dev. }\end{array}$ & Min & Max \\
\hline $\begin{array}{l}\text { Number of children in the household (aged less than } 15 \\
\text { years) }\end{array}$ & 2083923 & 0.007 & 0.120 & 0 & 6 \\
\hline Number of persons aged 65 or older in the household & 2083923 & 0.074 & 0.274 & 0 & 4 \\
\hline $\begin{array}{l}\text { Number of children in the household (aged less than } 25 \\
\text { years) }\end{array}$ & 2083923 & 0.012 & 0.145 & 0 & 6 \\
\hline $\begin{array}{l}\text { Number of employed persons in the household (aged } 15 \\
\text { years and more) }\end{array}$ & 2083923 & 1.006 & 0.741 & 0 & 9 \\
\hline $\begin{array}{l}\text { Number of employed adults in the household (aged 15 } \\
\text { years and more) }\end{array}$ & 2083923 & 1.006 & 0.740 & 0 & 9 \\
\hline $\begin{array}{l}\text { Number of unemployed adults in the household (aged 15 } \\
\text { years and more) }\end{array}$ & 2083923 & 0.071 & 0.272 & 0 & 5 \\
\hline $\begin{array}{l}\text { Number of inactive adults in the household (aged 15 years } \\
\text { and more) }\end{array}$ & 2083923 & 0.522 & 0.714 & 0 & 6 \\
\hline EPL regular contracts & 1895123 & 2.353 & 0.491 & 1.1 & 4.42 \\
\hline EPL temporary contracts & 1895123 & 1.468 & 0.840 & 0.38 & 3.75 \\
\hline $\begin{array}{l}\text { GDP growth rate in \% } \\
\text { ALMP expenditures in \% }\end{array}$ & 2864579 & 1.230 & 2.700 & -14.81 & 25.0 \\
\hline ALP124 & 0.864 & 0.455 & 0.05 & 2.05 \\
\hline
\end{tabular}

